\title{
Modelling Soil Erosion for Land Management in Ungauged Golole Catchment in Marsabit County, Kenya
}

\author{
Gabriel Nyagah Njiru ${ }^{1 *}$, Patrick Kariuki', Kennedy Mwetu ${ }^{2}$ \\ ${ }^{1}$ Department of Agricultural Resource Management, Kenyatta University, Nairobi, Kenya \\ ${ }^{2}$ Department of Geology, South Eastern Kenya University, Kitui, Kenya \\ Email: ^gab2pius@gmail.com
}

How to cite this paper: Njiru, G.N., Kariuki, P. and Mwetu, K. (2018) Modelling Soil Erosion for Land Management in Ungauged Golole Catchment in Marsabit County, Kenya. Open Journal of Soil Science, 8, 277-302.

https://doi.org/10.4236/ojss.2018.811021

Received: October 5, 2018

Accepted: November 10, 2018

Published: November 13, 2018

Copyright ( 2018 by authors and Scientific Research Publishing Inc. This work is licensed under the Creative Commons Attribution International License (CC BY 4.0).

http://creativecommons.org/licenses/by/4.0/

(c) (i) Open Access

\begin{abstract}
This study modeled soil erosion between January 2016 and September 2018 for land management in Golole catchment. The Revised Universal Soil Loss Equation (RUSLE) constituting the main agents of soil erosion was modeled in a Geographical Information System (GIS) environment. The objective of this study was to model soil erosion for land management in the ungauged Golole catchment. The Golole catchment soil erosion map reveals that within the catchment the soil loss was not homogeneous and erosion risk was not the same. The catchment experiences an annual mean score soil loss rate of $279 \mathrm{t} / \mathrm{ha}$ that is above the recommended maximum allowable annual soil loss rate of $4 \mathrm{t} / \mathrm{ha}$. The catchment's soil loss rate is described as high and severe representing $70 \%$ and $30 \%$ of landmass respectively. This study found the need to decelerate the above soil loss rates to moderate and low levels by adopting soil erosion mitigation measures such as stone contour ridges, manure, strip cropping, and terracing in the cultivated areas and controlled grazing in the lowland rangeland. The study strongly felt the need to protect the forest reserve from tree cutting and further human encroachment. This study concludes that there is the need for further research 1) in the forest reserve areas that showed the greatest rates of soil erosion menace to determine the underlying causes, and 2) to assess the temporal trends of the soil erosion hazard using high-resolution data.
\end{abstract}

\section{Keywords}

Catchment, Soil Loss, Erosivity, Erodibility, Erosion Modeling, ArcGIS, RUSLE 


\section{Introduction}

Golole catchment located in Marsabit County, Kenya is prone to soil erosion menace that is accelerated by intensive and extensive farming, overgrazing and deforestation. Rill and sheet erosion by water occurring in undisturbed lands like pasturelands and rangelands was accelerated by overgrazing [1]. Globally soil erosion is a common natural disaster that leads to the decline of soil fertility, water quality and hence unsustainable agricultural production [2].

Soil erosion and degradation of land resources are highly significant spatio-temporal phenomena in many countries [3]. Soil erosion remains a key socio economic and ecological problem in Kenya affecting all sectors of the economy; agriculture, hydropower, fisheries and tourism [3] [4]. Soil is a limited and irreplaceable resource and its loss renders fertile lands barren [5]. The ability to quantify soil loss contributes to effective soil erosion control though the complexity of the variables involved makes prediction of soil loss rate difficult [5] [6].

Scientific planning for soil and water conservation requires the knowledge of factors that either cause or reduce soil and water loss respectively; leading to specific guidelines that are needed for selecting the control practices best suited to the particular needs of each site [7]. Severe erosion prone areas can be delineated and prioritized for erosion mitigation [8]. Effective soil erosion control requires prediction of the amount of soil loss [5] [9].

The soil erosion models used to quantify soil loss include; the Revised Soil Loss Equation (RUSLE), European Soil Erosion Model (EUROSEM), the Limberg Soil Erosion Model (LISEM) and the Chemical Runoff and Erosion from Agricultural Management Systems (CREAMS) to name but a few. The Universal Soil Loss Equation (USLE), a precursor to RUSLE was revised to incorporate evolving technology since 1998 to more accurately estimate soil loss from both cropped and rangeland areas [7] [10].

RUSLE is used to predict erosion rate of an ungauged catchment [11]. RUSLE constitutes the main factors causing soil erosion: rainfall erosivity, soil erodibility, slope length, steepness, cover management and support practice [12]. The choice and use of RUSLE model in this study to quantify soil was informed by its all-inclusive representation of the main factors that cause soil erosion [9]. RUSLE in GIS allows use and analysis of vast amounts of data that would otherwise not be feasible manually [13]. RUSLE was the official tool used for conservation planning in United States of America (USA) and in many other countries [14].

The magnitude of soil loss was predominantly determined by erosivity and erodibility [15]. Erosivity is associated with the rainfall, being a measure of forces applied to the soil causing soil detachment and transportation while erodibility is dependent on the soil physical chemical characteristics, being a measure of the susceptibility of the soil to erode. Soil erosion is highly dependent on the land gradient while anthropogenic activities aggravate soil erosion through 
the alteration of land cover and use [2].

Identifying high-risk areas of soil erosion increases the effectiveness of soil mitigation measures while at the same time reduces soil erosion mitigation cost [13]. The effects of soil erosion in Golole catchment was the rapid siltation of water reservoirs due to high amount of soil brought from the upper parts of the catchment. The objective of this study was to model soil erosion for land management in the ungauged Golole catchment through simulation of the spatial soil loss, delineation of risky areas of soil erosion as well as suggesting mitigation measures of soil erosion on risk areas delineate.

This research successfully modeled the spatial rate of soil loss within Golole catchment using remote sensed data, digital data in a digital environment as well as ground truthing. The use of digital environment allowed delineation of soil loss severity areas with ease. The digital soil loss map of the catchment demonstrated use in suggesting targeted, appropriate and economical soil erosion mitigation measures that could be used by farmers, policy makers and researchers.

\section{Methodology}

\subsection{Study Area}

The study area is located on the Eastern slopes of Mt. Marsabit within the Marsabit volcanic zone and administratively in the central region of Marsabit County (Figure 1). Mt. Marsabit lying about $1500 \mathrm{~m}$ above mean sea level is centrally located. The study area exhibits undulating terrain with isolated steep slopes and hills occupying an area of 1886 Square km lying between latitude $2^{\circ} 0^{\prime} 0^{\prime \prime}$ and $2^{\circ} 24^{\prime} 47^{\prime \prime}$ North and longitude $37^{\circ} 53^{\prime} 17^{\prime \prime}$ and $38^{\circ} 28^{\prime} 8^{\prime \prime}$ East as shown in the map of Marsabit County (Figure 1). The area stretches $67 \mathrm{~km}$ with the widest section measuring $35 \mathrm{~km}$. According to Kenya ecological zones (Appendix I, Table A1), the study area ecologically varies from semi-humid to semi-arid with a mean annual rainfall of $875 \mathrm{~mm}$.

The study area soils can be described as well drained, moderately deep, dark reddish, brown to dark red friable clay textured as detailed in Appendix VI, the major soil properties of the study area (Table A2). According to FAO soil classification, the study area soils varied geographically comprising of lithosols, chromic cambisols, pellic vertisaols, eutric nitosols, mollic andosols, calcic xerosols/yermosols and calcic fluvisols. The area land cover includes woody trees, low shrubs and herbaceous plants. The area boasts of herbaceous crops and a dendritic drainage pattern of ephemeral rivers.

\subsection{Simulating Soil Loss Using RUSLE}

In this study the RUSLE algorithms shown in Table 1 were used to derive the five RUSLE thematic layers (factors). The layers were combined to derive the study area soil erosion map. The steps followed to derive RUSLE thematic layers are outlined below.

Rainfall factor. The Kenya rainfall grid was used to derive the study area 


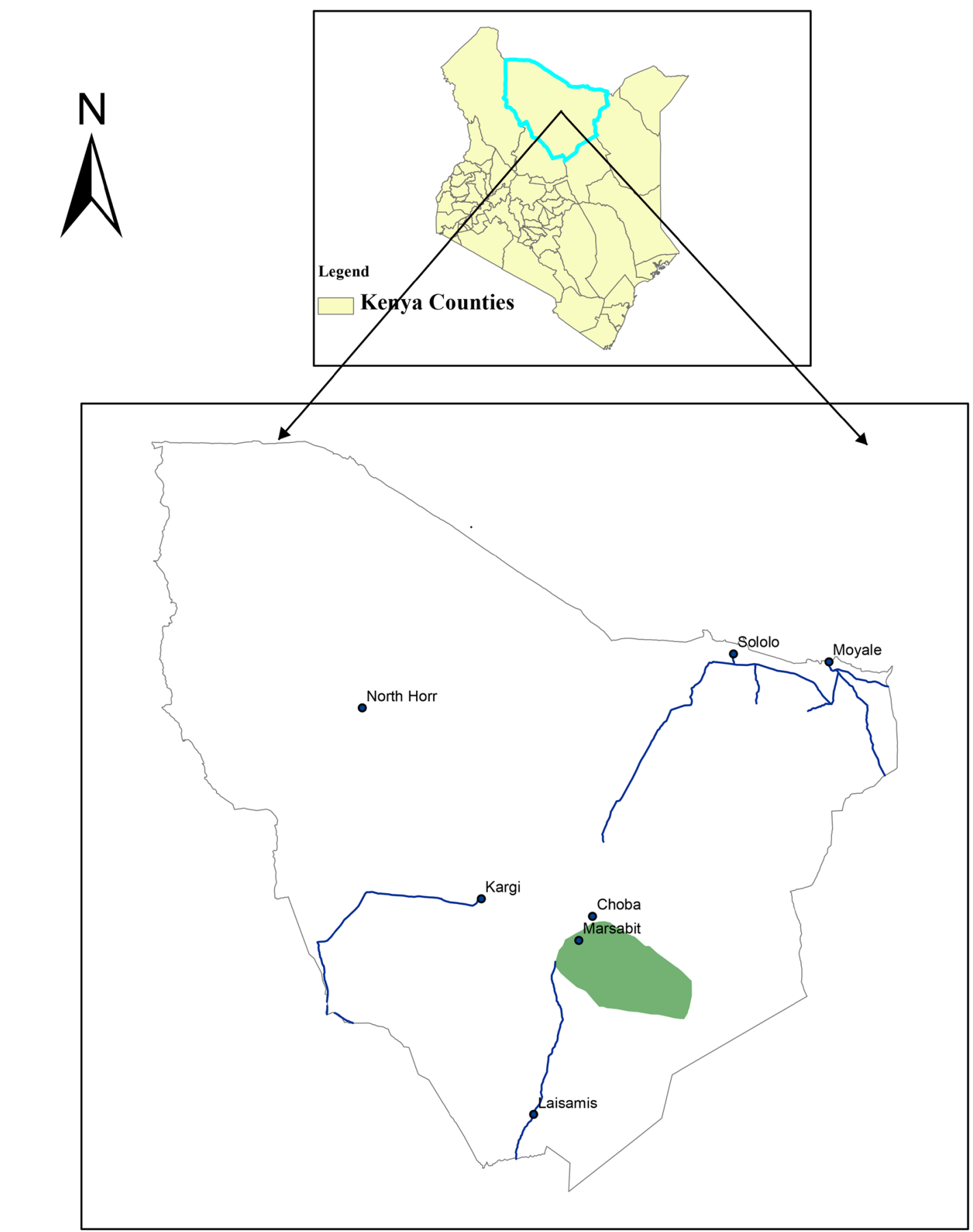

\section{Legend}

- Marsabit County major towns

- Marsabit major roads

\section{Study area}

Marsabit County

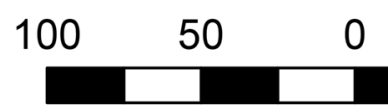

100 Kilometers

Figure 1. Map showing the study area in Marsabit county, Kenya. 
Table 1. RUSLE factors algorithms.

\begin{tabular}{cc}
\hline Factor & Algorithms \\
\hline Rainfall factor & $R=-8.12+(0.56 \times P)$
\end{tabular}

$R$ is the rainfall factor and $P$ is the mean annual rainfall [17]

Soil erodibility factor

$$
K=27.66 m^{1.14} \times 10^{-8} \times(12-a)+0.0043 \times(b-2)+0.0033 \times(c-3)
$$

$K=$ Soil erodability factor (ton $\left.\cdot \mathrm{hr}^{-1} \cdot \mathrm{ha}^{-1} \cdot \mathrm{MJ} \cdot \mathrm{mm}\right), m=($ Silt\% + Sand $\%) \times$ (100 - clay\%), $a=\%$ organic matter, $b=$ structure code: 1 ) very structured or particulate, 2) fairly structured, 3) slightly structured, and 4) solid, $c=$ profile Permeability code: 1) rapid, 2) moderate to rapid, 3) moderate, 4) moderate to slow, 5) slow, 6) very slow [7]

Equation used to derive soil organic matter

$$
S O M=1.72 \times O C
$$

$S O M$ is the soil organic matter and $O C$ is the soil percentage organic carbon content [20]

Slope length factor

$$
\begin{aligned}
L S= & ([\text { Flow accumulation }] \times[\text { cellsize }] / 22.1)^{0.4} \\
& \times[\sin (\text { localslope }(\text { degrees })) \times 0.0896 / 0.0896]^{1.3}
\end{aligned}
$$

$L S$ is the length slope factor; flow accumulation is the number of cells contributing to flow into a given cell. Cell size is the ground resolution of 30 meters [22] [23]

Land cover factor

Equation used to calculate landsat image reflectance value:

$$
\rho \lambda=M \rho Q c a l+A \rho
$$

Where $\rho \lambda$ is the TOA planetary reflectance, $M \rho$ is band multiplicative rescaling factor, $Q c a l$ is quantized and calibrated standard product pixel values $(\mathrm{DN})$ and $A \rho$ is the band specific additive rescaling factor Equation used to correct reflectance for the sun angle:

$$
\rho \lambda=\rho \lambda / \cos \Phi \mathrm{SZ}=\rho \lambda / \sin \Phi \mathrm{SE}
$$

where $\rho \lambda$ is the Top of Atmosphere (TOA) planetary reflectance, $\Phi$ SE is the local sun elevation angle (Sun Elevation), $\Phi \mathrm{SZ}$ is the local solar zenith angle $\left(\Phi \mathrm{SZ}=90^{\circ}-\Phi \mathrm{SE}\right)$

Equation used to calculate the Normalized Difference Vegetation Index (NDVI)

$$
\text { NDVI }=\frac{\text { Band } 5-\text { Band } 4}{\text { Band5 }+ \text { Band } 4}
$$

Where band 4 is the red band while band 5 is the infra-red band Equation used to estimate the land cover factor

$$
C_{r}=\left[\left(-\mathrm{NDVI}+\frac{1}{2}\right)\right]
$$

where $C_{r}$ is the land cover factor [24] [25]

Practice factor

This was derived through a process outlined below

Soil loss

The five RUSLE factors were overlaid to derive the soil loss

$$
A=R \times K \times L S \times C \times P
$$

where $A$ is the soil loss, $R$ is the rainfall, $K$ is the soil, $L S$ is the slope length, $C$ is the crop and $P$ is the practice factors 
rainfall grid map [16]. The Hurni's empirical equation shown in the RUSLE factors algorithms (Table 1), was used to derive the rainfall factor [17]. The rainfall data for Marsabit meteorological station located within the study area was used to validate the rainfall grid data [18].

Soil factor (K-factor). The digital soil map used to derive the K-factor maps was the revised soil map of Kenya [19]. The K-factor was derived using the soil factor equations shown in the RUSLE factors algorithms (Table 1) [7] [10]. The soil organic matter parameter was indirectly derived from the digital soil map [20]. The $\mathrm{K}$ factor was based on a scale from 0 to 1 , where 0 refers to soils with least susceptibility to erosion and 1 to soils which are highly susceptible to erosion by water.

Slope length (LS) factor. The digital elevation model (DEM) with a ground resolution of 30 metres was derived from the Advanced Spaceborne Thermal Emission and Reflection (ASTER) [21]. The LS-factor parameter maps: DEM sink filled, flow direction, flow accumulation and slope gradient maps were derived independently using equation shown in the RUSLE factors algorithms (Table 1) [22] [23].

Land cover factor (C). The $\mathrm{C}$-factor is a relation between erosion on bare soil and a land cover type and density, adopting a value of 1 for bare soils and less that one for more reducing erosion land cover. The Normalized Difference Vegetation Index (NDVI) map was derived from Landsat image of the study area and processed for reflectance value, reflectance correction and NDVI and finally the land cover factor using equations shown in the RUSLE factors algorithms (Table 1) [19] [24] [25].

Practice factor. The percentage slope and major land use concept was adopted in this study. The practice factor was influenced by slope and two categories of landuse that is agriculture and non-agricultural [7]. The practice factor values range from 0 to 1 with the lower values indicating better practice for controlling soil erosion. The Africover landcover map of 2014 produced from the Enhanced LANDSAT TM images was used to derive the major land uses in the study area. The slope categories were derived from the DEM of the study area [19].

The two major land uses (agricultural and non-agricultural) and the DEM percentage polygon map were overlaid in arcGIS to produce the study area map with the two major land uses flagged by their respective percentage slope as shown in the conservation practice factors (Table 2). The agricultural lands were classified into six slope categories and assigned p-values respectively while all non-agricultural lands were assigned a p-value of 1 as shown in the conservation practice (Table 2). Several GPS points were used to validate the landuse type as shown by the control points map in Figure 2 .

Soil loss. The five RUSLE thematic layers were overlaid to derive the soil erosion map using RUSLE equation shown in the RUSLE factors algorithms (Table 1). The risky areas of soil erosion were identified by reclassification of the soil erosion map into five classes. The soil loss was compared with the tolerable soil 
Table 2. Conservation practice factors [7]

\begin{tabular}{ccc}
\hline Land use & Percentage slope & P-factor \\
\hline $0.00-5.00$ & 0.10 \\
$5.00-10.00$ & 0.12 \\
Agriculture & $10.00-20.00$ & 0.14 \\
& $20.00-30.00$ & 0.19 \\
& $30.00-50.00$ & 0.25 \\
Other land & $50.00-100.00$ & 0.33 \\
\hline
\end{tabular}

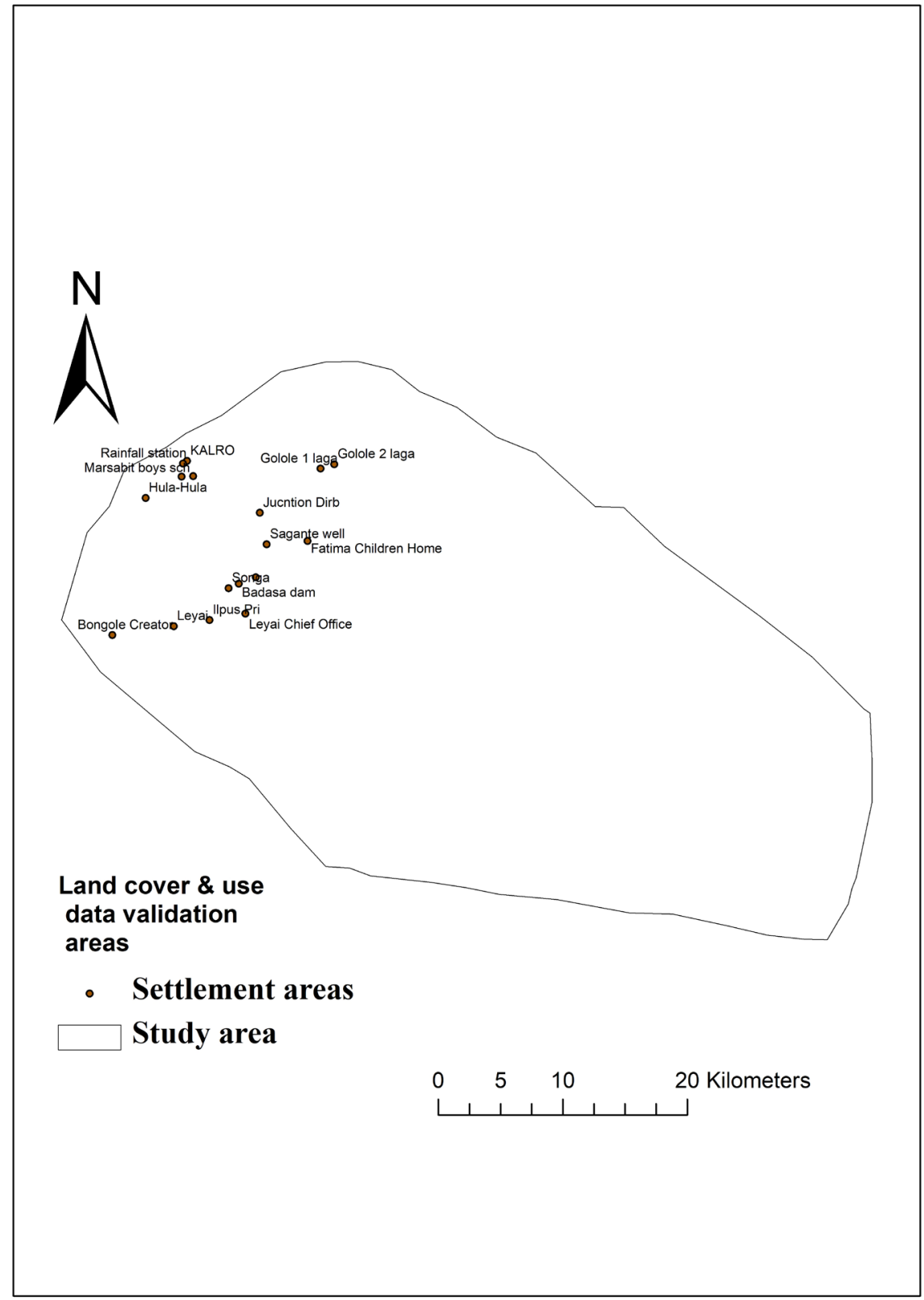

Figure 2. Control points used to validate the land cover and land use. 
loss recommended for the area in order to determine the type of erosion risk.

\section{Results}

\subsection{Simulated Spatial Soil Loss}

Rainfall factor. The Marsabit weather station rainfall amount for the year 1998 was $893 \mathrm{~mm}$ that corresponded to the grid with annual rainfall amount of 806 $\mathrm{mm}$ shown in the rainfall grid of the study area (Figure 3 ) translated into a percentage difference of 9.7\%. The high and low rainfall was in high and low parts of the catchment respectively. The highest and lowest rainfall factors were 460 and 201 respectively shown in the rainfall factor map Figure 4.

Soil erodibility factor. The maps representing the soil factor equation shown in RUSLE factors algorithms (Table 1) are described in the soil factor parameter (Table 3) and presented in the soil erodibility factor maps (Appendix II) [7].

The study area showed that the soil erodibility factor $(\mathrm{K})$ ranged between 0.004 and 0.058 with a mean score of 0.045 and standard deviation of 0.015 as shown in the soil erodibility factor map (Figure 5 ). The soil structure and profile permeability were categorized under three structural codes (2, 3 and 4$)$ and $(2,3$ and 5) respectively [7] [10]. The predominant soil structure was code 3 and 4 described as fairly to slightly structured soil while the profile permeability predominantly was coded as 3 and 5 described as moderate to slow. The soil organic matter was below $1 \%$. The major soil properties of the study area are described in Appendix VI.

Length slope factor (LS-factor). The maps representing the length slope factor equation shown in the RUSLE factors algorithms (Table 1) are described in the LS factor parameters (Table 4) and presented in the LS factor parameters (Appendix III) [22].

The LS mean score was 1 with a standard deviation of 5 while the minimum and maximum was 0 and 231 respectively as shown in the slope length factor map Figure 6.

Land cover factor (C.). The maps representing the $\mathrm{C}$-factor equations shown in the RUSLE factors algorithms (Table 1) are described in the C-factor parameters (Table 5) and presented in the c-factor parameters maps (Appendix IV) [24] [25].

The study area $\mathrm{C}$-factor values ranged between -0.045 and 0.58 with a mean score of 0.366 and standard deviation of 0.08 as shown in the land cover factor map (Figure 7).

Modified practice factor (P). The land use map showing agricultural and non-agricultural areas and reclassified slope map of the study area (Figure A12) and (Figure A14) respectively are shown in the P-factor maps (Figure A13). $\mathrm{P}$-factor ranged from 0.10 to 1 with a mean value of 0.94 and standard deviation of 0.22 as shown in the practice factor map (Figure 8).

Study area soil loss. The maximum and minimum spatial distribution of 
annual soil loss rate within the catchment was $494 \mathrm{t} / \mathrm{ha}$ and $203 \mathrm{t} / \mathrm{ha}$ respectively as shown in the soil loss map (Figure 9).

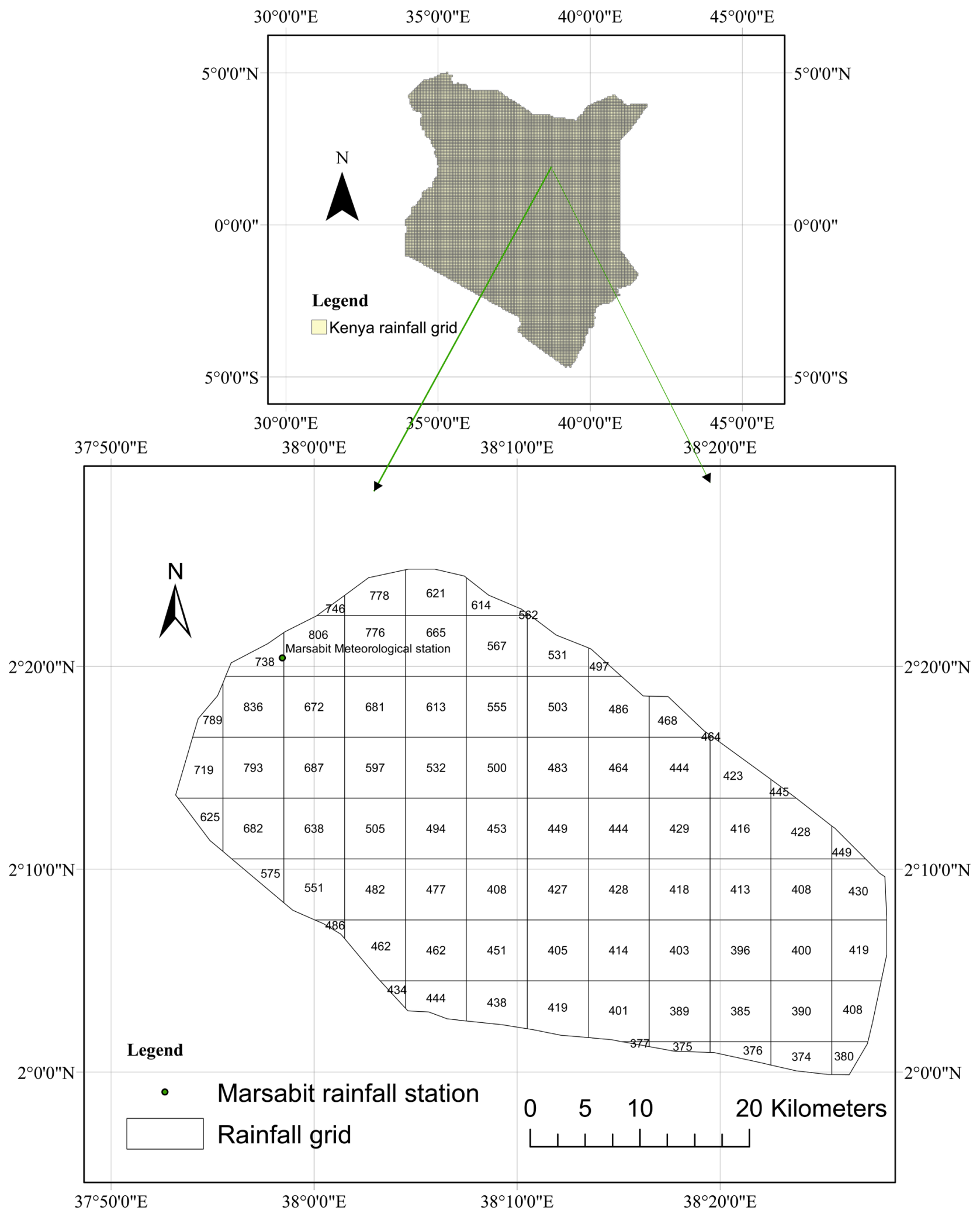

Figure 3. Rainfall grid of the study area. 


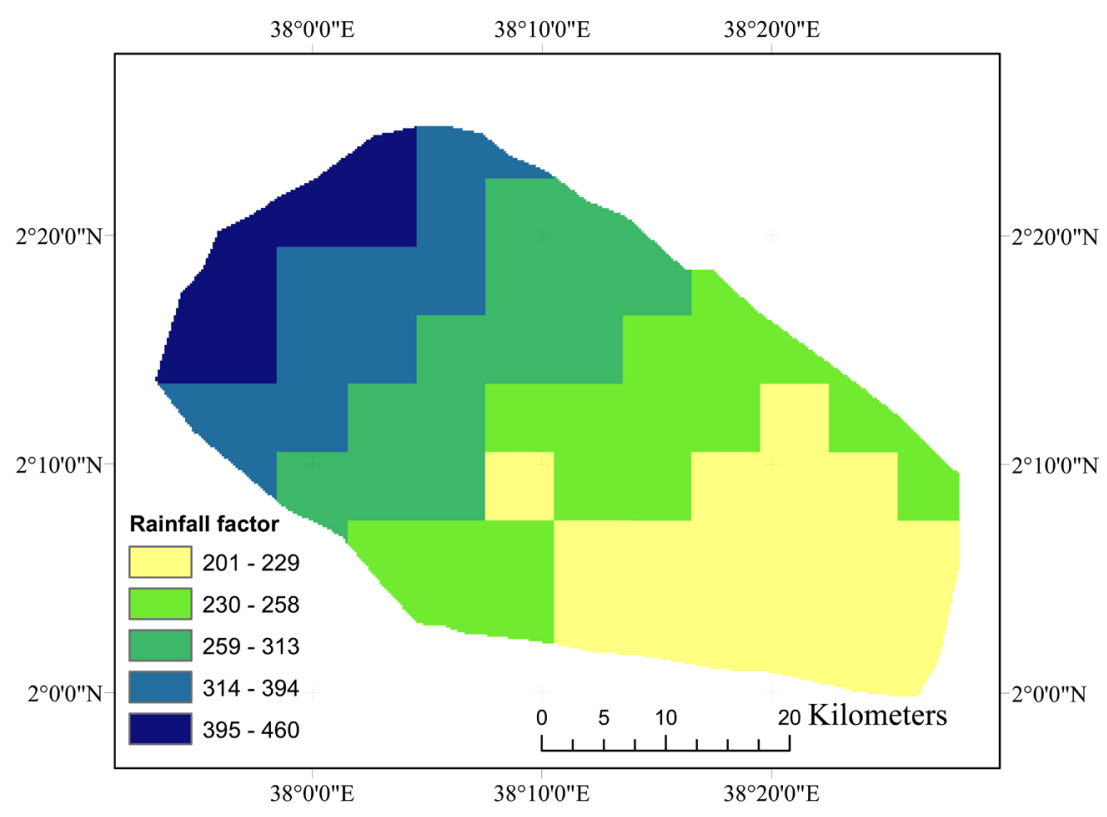

Figure 4. Rainfall factor map.

Table 3. Soil factor parameters.

\begin{tabular}{ccc}
\hline No. & Soil parameter & Description of the soil of parameter \\
\hline 1 & Silt Figure A1 & $12.00 \%-30.00 \%$ \\
2 & Sand Figure A2 & $17.00 \%-42.00 \%$ \\
3 & Clay Figure A3 & $35.00 \%-70.00 \%$ \\
4 & Soil organic matter Figure A4 & $0.700 \%-1.100 \%$ \\
5 & Soil structure code Figure A5 & 2,3 and 4 \\
6 & Soil permeability code Figure A6 & 2,3 and 5 \\
\hline
\end{tabular}

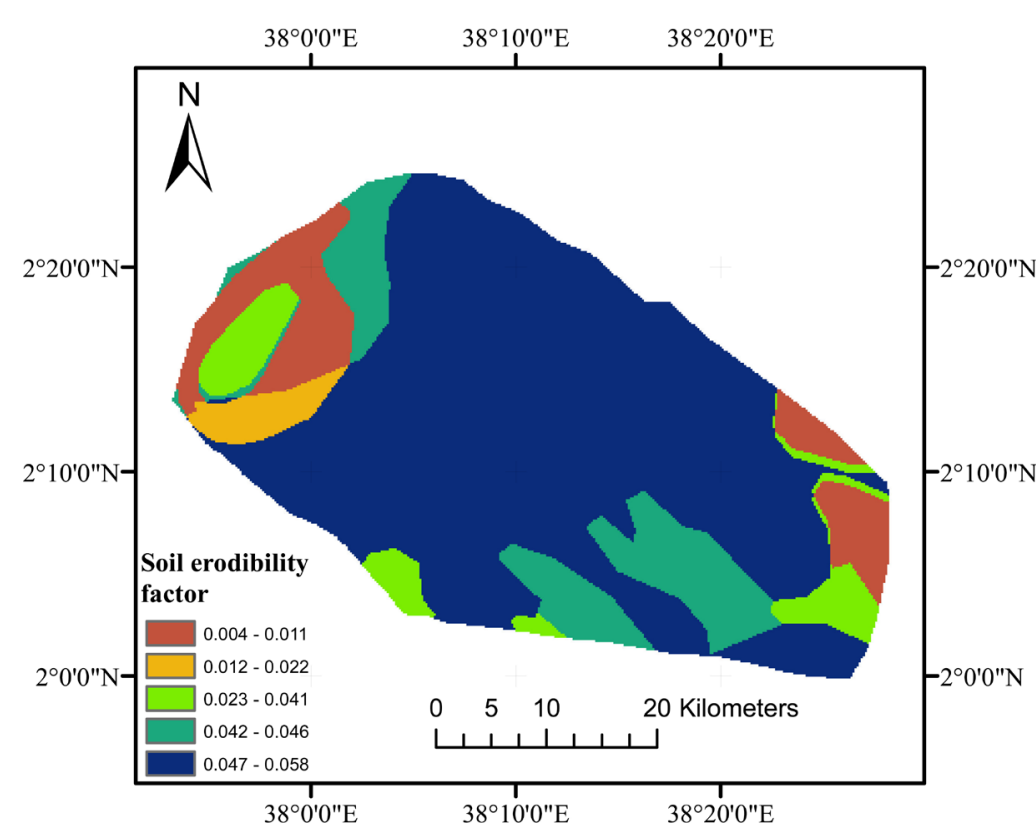

Figure 5. Soil erodibility factor map. 
Table 4. LS-factor parameters.

\begin{tabular}{ccc}
\hline No. & LS parameter & Description of the LS parameter \\
\hline 1 & Sink filled map-Figure A7 & $326-1681$ \\
2 & Flow direction map-Figure A8 & $1-65$ \\
3 & Flow accumulation-Figure A9 & $0-602,549$ cells \\
4 & Slope gradient-Figure A10 & $0-58$ degrees \\
\hline
\end{tabular}

Table 5. C-factor parameters.

\begin{tabular}{ccc}
\hline No. & C-parameter & Description of the C parameter \\
\hline 1 & Regional NDVI-Figure A11 & -1.00 to 1.00 \\
2 & Study area NDVI-Figure A12 & -0.08 to 0.55 \\
\hline
\end{tabular}

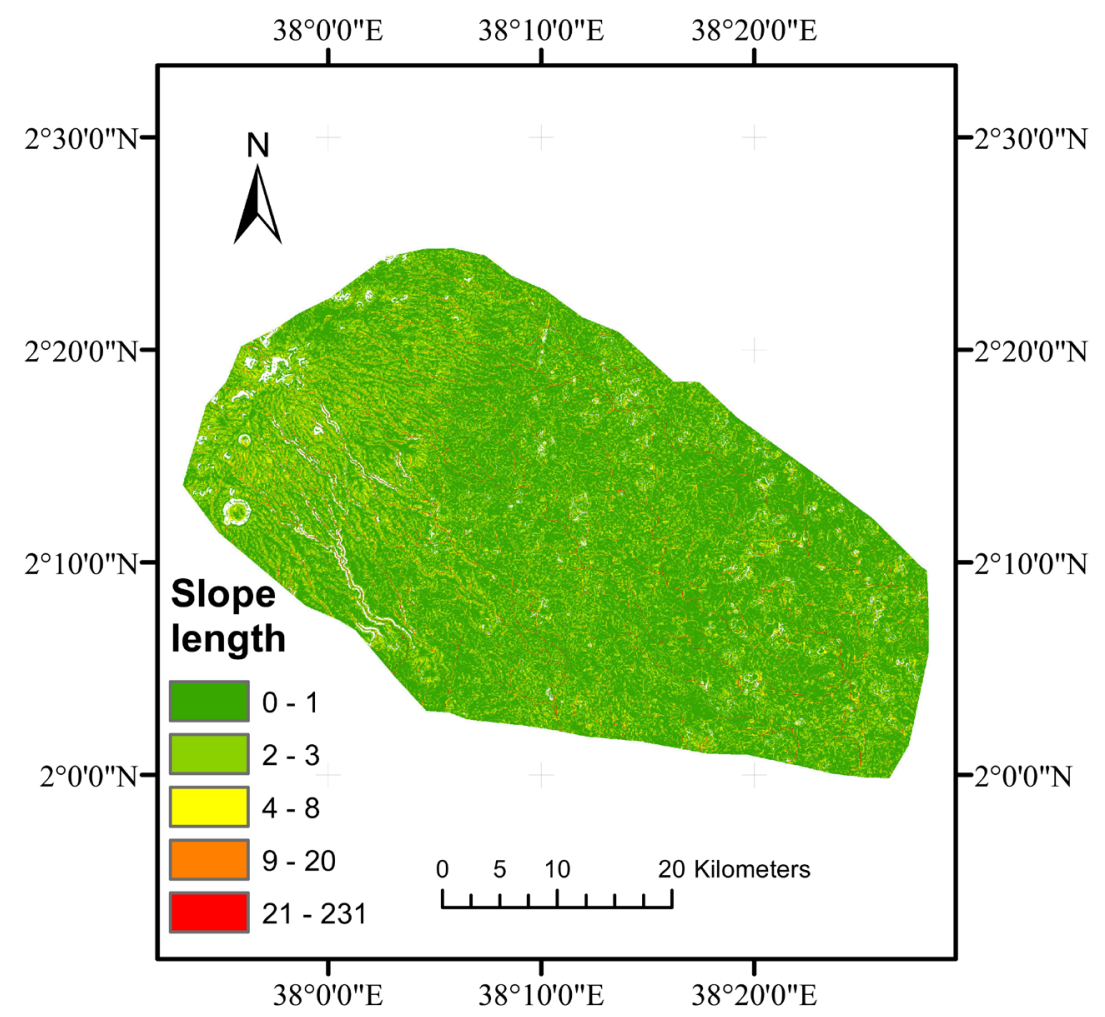

Figure 6. Slope length factor map.

\subsection{Zoned Erosion Risk Areas}

The values of annual soil loss range within the study area are shown in Table 6 . The smallest value is $202.00 \mathrm{t} / \mathrm{ha}$ while the highest value is $493.00 \mathrm{t} / \mathrm{ha}$ eroded from the area of $833.00 \mathrm{~km}^{2}$ and $30.00 \mathrm{~km}^{2}$ respectively.

The study adopted the soil loss severity classes (Table 7) [9] [26].

From Table 7, 70\% of the study area was classified under high erosion level while the remaining $30 \%$ was classified as severe.

Ground truthing. The vegetation cover in the cultivated area was not uniform ranging from thick vegetation cover to bare land. The upper part of the 
catchment above $1100 \mathrm{~m}$ a.s.l. occupied by the forest was covered by thick vegetation mainly shrubs and trees. The forest area was hilly, with undulating terrain and home to wildlife (elephants, buffalos, monkeys, antelopes among others). Deforestation (cutting of trees) as well as human encroachment on the forest land was noted in areas bordering the forest.

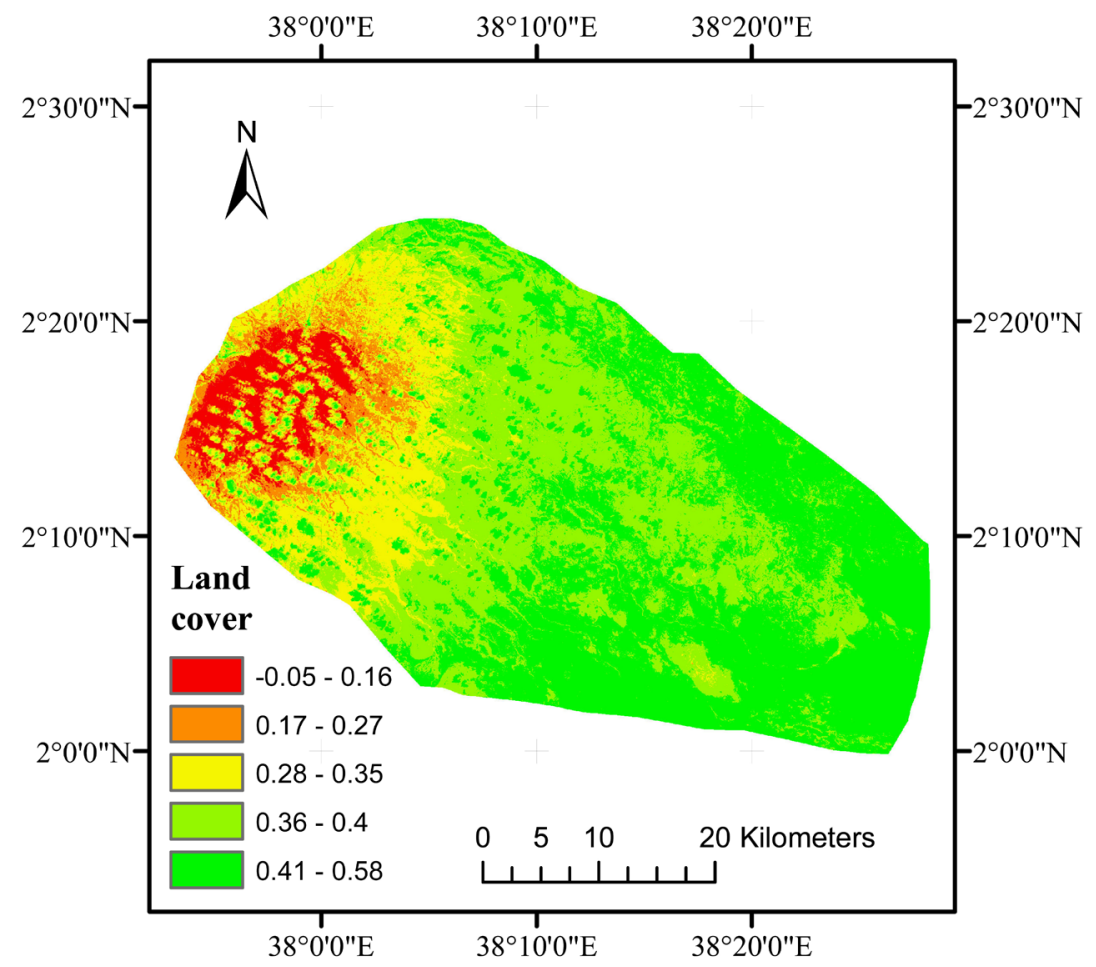

Figure 7. Land cover factor map.

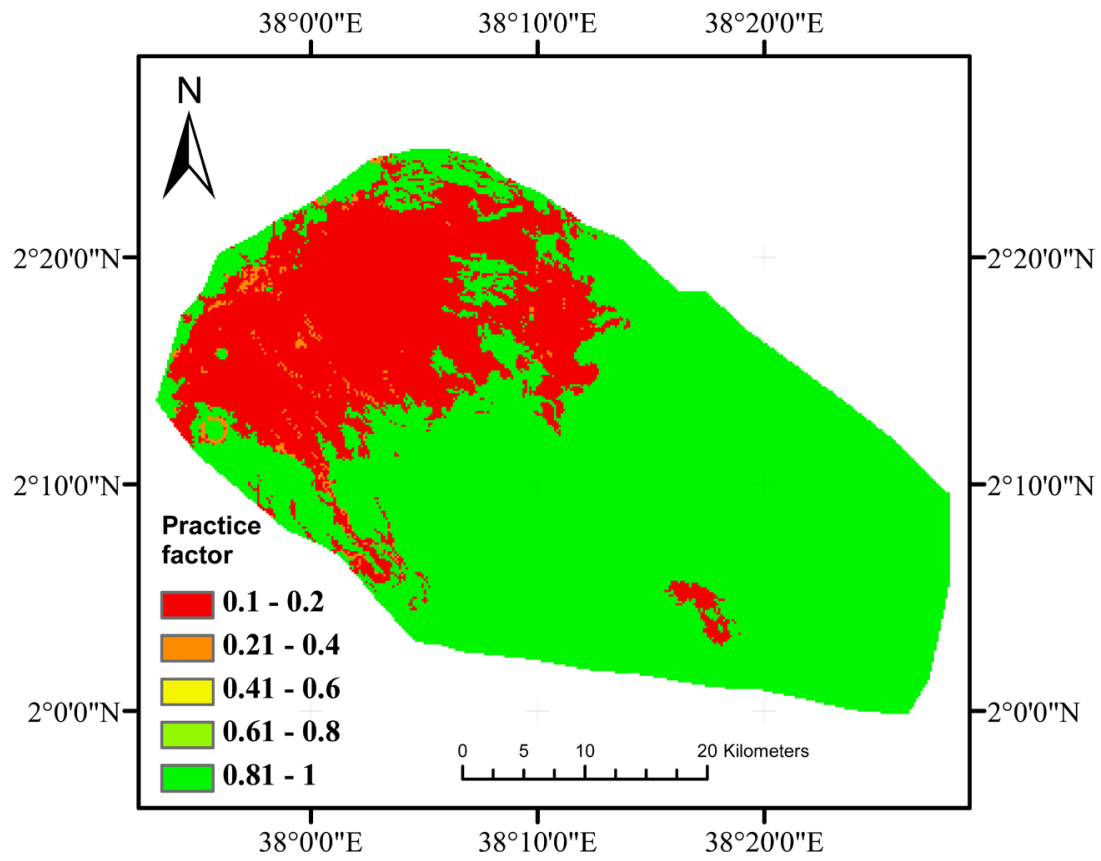

Figure 8. Practice factor map. 


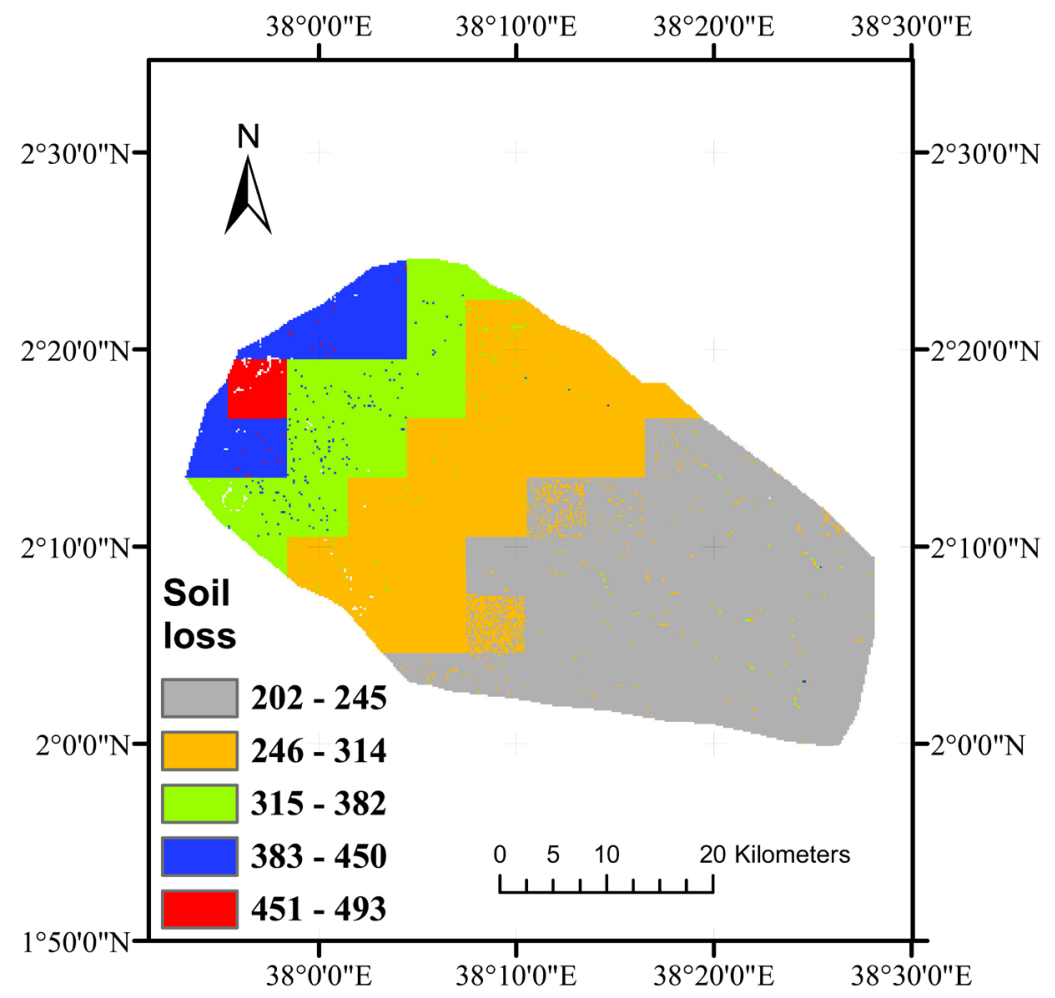

Figure 9. Soil loss map.

Table 6. Range of area of annual soil loss values.

\begin{tabular}{cccc}
\hline No & Annual soil loss range value (t/ha) & Area in Sq. km & Area in \% \\
\hline 1 & $202.00-245.00$ & 833.00 & $45.00 \%$ \\
2 & $246.00-314.00$ & 551.00 & $30.00 \%$ \\
3 & $315.00-382.00$ & 293.00 & $15.00 \%$ \\
4 & $383.00-450.00$ & 142.00 & $8.00 \%$ \\
5 & $451.00-493.00$ & 30.00 & $2.00 \%$ \\
\hline
\end{tabular}

Table 7. Soil loss severity classes.

\begin{tabular}{ccccc}
\hline No & Annual soil loss range value (t/ha) & Soil loss severity classes & Area in Sq. km & Area in \% \\
\hline 1 & $<10$ & Nil & 0 & 0 \\
2 & $10-50$ & Low & 0 & 0 \\
3 & $50-150$ & Moderate & 0 & 0 \\
4 & $150-300$ & High & 1293 & $70 \%$ \\
5 & $>300$ & Severe & 556 & $30 \%$ \\
\hline
\end{tabular}

The surface water sources comprising of earth pans and dams were heavily silted due to the high amount of soil brought from the upper reaches of the catchment. Rills and gullies were observed on hilltops and on steep slope terrains. In the cultivation areas few farms used stone contour ridges. The rangelands occupying the lowland plains vegetation was depleted to bare land due to over- 
grazing.

\section{Discussion}

The derivation of RUSLE factors using appropriate algorithms, digital elevation model (DEM), digital maps and remote sensed data in a GIS environment yielded more accurate estimation of RUSLE factors particularly those derived from 1) remote sensed data (land cover factor), and 2) digital elevation model (slope length and practice factor). In this study the derived rainfall factor spatial pattern showed a progressive rise in the rainfall factor from the lower to upper parts of the catchment as shown in the rainfall factor map (Figure 4). Similar pattern was exhibited on the overall soil loss rate. A similar trend was found for rainfall factor for Kapingazi River catchment in Kenya [27].

The soils of the study area exhibited low erodibility as shown by soil erodibility factor map (Figure 5). It also reflected very low organic matter, slightly structured and slow to moderate permeability class shown in the soil erodibility factor maps (Appendix II and Appendix VI). As a result, this soil is prone to high erodibility. The presence of soil organic matter in the soil in varying degrees increases soil porosity and capacity to hold water which in turn reduces soil erodability [28]. While information on organic matter, soil structure and profile permeability class add erodibility prediction accuracy, soil becomes less erodible with decrease in silt fraction [7]. Sand, sandy loam, and loam soils are less erodible than silt, very fine sand and certain clay soils [29]. The study area soil texture can be described as predominantly loamy clayey (Appendix VI) probably being the reason for its low erodibility due to increased soil cohesiveness. As clay fraction increases, erodibility decreases, a phenomenon probably attributable to the increased cohesiveness [29].

The study observed that topography played a major role in influencing the rate of soil erosion. This was noted due to the high spatial correlation observed between the slope length factor and soil loss rate (Figure 6 and Figure 9 respectively). In this case, the two were compared using similar coordinates and showed similar trends where high or low slope length factor meant high or low rate of soil loss. The severe erosion rates occurred in hilly, steep and undulating terrains as shown by the slope length factor map and soil loss map (Figure 6 and Figure 9 respectively). A similar correlation was noted using RUSLE and geo-information technology in a small sub-watershed in Kerala, India [6].

The study observed minimal land cover in the cultivated areas that also exhibited high soil loss shown by the land cover factor map and practice factor map (Figure 7 and Figure 8 respectively). The research results showed high rate of soil erosion in Marsabit mountain ecosystem (highlands) that occurred in areas with less or no vegetation cover [30]. The results showed that land cover constituted the most important factor that could be economically manipulated through management and conservation measures to greatly reduce soil loss [10]. The findings in this study agree with the observation that the high rates of ero- 
sion in Ethiopia was caused by: deforestation, overgrazing, detrimental cultivation practices, poverty, land fragmentation and expansion of cropland [31].

This study found that the high and low soil loss rates occurred in the highlands and lowlands respectively as shown in the soil loss map (Figure 9). The soil loss within the catchment was not homogeneous and varied significantly from one area to another with an annual mean score of $272 \mathrm{t} / \mathrm{ha}$. The estimated soil loss rates are reliable and strongly indicate the urgency for soil conservation in the study area. The other researchers using RUSLE in a GIS environment got an annual average soil loss rate of $600 \mathrm{t} / \mathrm{ha}$ for Taita hills in Kenya [32], $93 \mathrm{t} / \mathrm{ha}$ from Chemoga Blue Nile Basin, Ethiopia [8] and $42 \mathrm{t} / \mathrm{ha}$ from cultivated fields in Ethiopia [33].

The study delineated risk areas of soil erosion according to soil loss severity classes (Table 7) where $30 \%$ of the study area land mass experienced severe soil loss rates. The study acknowledges that the entire catchment was prone to accelerated erosion since the minimum annual soil loss rate of $202 \mathrm{t} /$ ha was above the recommended annual soil erosion tolerable level of $4.8 \mathrm{t} / \mathrm{ha}$ for the area [34].

This study found that lack of vegetation cover and type of land use (cultivation and grazing) were the main contributors to the severe and high rate of soil loss in the study area. RUSLE factors can be classified into two categories; environmental and management with the former remaining relatively constant over time while the latter varies considerably [9]. This implies that the management factors affecting both land cover and land use can be manipulated considerably to reduce the rate of the soil loss. Therefore, cultivation on the eastern slopes of Mt. Marsabit especially below $1300 \mathrm{~m}$ a.s.l. should be reduced due to soil erosion hazard [35].

\section{Conclusions}

The study achieved its objectives having simulated the spatial soil loss, delineated risky areas of soil erosion and suggested mitigation measures. The study identified areas with severe annual soil loss rates as the cultivated forest reserve and hilly areas. The study findings agree extensively with similar research undertaken in other parts of the world as noted in the discussion section. The study concludes that the high and severe erosion rates associated with the study area should be addressed in order to scale down the rate of annual soil loss to moderate and low levels.

This study recommends use of stone contour ridges, manure, strip cropping, and terracing in the cultivated areas and controlled grazing in the lowland rangeland. The abundance of natural stones in the study area makes the use of stone contour ridges feasible. Stone walls reduce slope length and hence reduce soil erosion especially in hilly areas [36]. There is need to increase the soil organic matter levels in order to build the soil nutrient buffer and improve soil water holding capacity. This study also acknowledges the imperative need to protect the forest area from tree cutting and further human encroachment. The local 
communities should adopt and prioritize soil conservation measures in the cultivated lands by applying alternative soil protective methods as enumerated above. The local planners and decision makers should also implement both short term and long-term measures of curbing soil erosion including afforestation and forest protection. This study recommends further research in the forest reserve areas that showed the greatest rates of soil erosion menace to determine underlying causes and appropriate soil erosion mitigation measures. Further research to assess the temporal trends of the soil erosion hazard uses high resolution data.

\section{Acknowledgements}

Sincere gratitude goes to the proposal review committee for their sincere criticism, variable inputs, insightful comments, and encouragement. Special mention goes to the Chairperson, Department of Agricultural Resource Management, Kenyatta University. The Regional Centre for Mapping of Resources and Development, and (Kenya Meteorological Department, Nairobi for the rainfall data. Special thanks go to the Institute Director, Kenya Agricultural and Livestock Research Organization (KALRO) Marsabit, for the library facilities.

\section{Conflicts of Interest}

The authors declare no conflicts of interest regarding the publication of this paper.

\section{References}

[1] Foster, G.R, Toy, T.E. and Renard K.G. (2003) Comparison of the USLE, RUSLE 1 and RUSLE 2 for Application in the Highly Disturbed Lands. First Interagency Conference, Benson, 27-30 October 2003, 154-160.

[2] Yang, D., Shinjiro, K., Taikano, O., Toshio, K. and Katumi, M. (2003) Global Potential Soil Erosion with Reference to Land Use and Climate. Hydrological Process, 17, 2913-2928.

[3] Fistikoglu, O. and Harmacioglu, N. (2002) Integration of GIS with USLE in Assessment of Soil Erosion. Water Resources Management, 16, 447-476. https://doi.org/10.1023/A:1022282125760

[4] Dominik, F., Robert, B., Malcolm, M., Manfred, M., Mathias, V., Tim, R., Julia, E. and Stephen E. (2007) East Africa Soil Erosion Recorded in a 300 Year Old Coral Colony from Kenya. Geographical Research Letters, 34, L04401,

[5] Ishtiyaq, A. and Verma, M. (2013) Application of USLE Model \& GIS in Estimation of Soil Erosion for Tandula Reservoir. International Journal of Emerging Technologies and Advanced Engineering, 3, 570-576.

[6] Prasannakumar, V., Vijith, H. and Geetha, N. (2011) Estimation of Soil Erosion Risk within a Small Mountainous Sub-Watershed in Kerala, India, Using Revised Universal Soil Loss Equation (RUSLE) and Geoinformation Technology. Geoscience Frontiers, 3, 209-215. https://doi.org/10.1016/j.gsf.2011.11.003

[7] Wischmeier, W. and Smith, D. (1978) Predicting Rainfall Erosion Losses: A Guide to Conservation Planning Agricultural Handbook. N0. 537, Prepared by Science and Education Administration, US Department of Agriculture, Washington DC. 
[8] Bewket, W. and Teferi, E. (2009) Assessment of Soil Erosion Hazard and Prioritization for Treatment at the Watershed Level: A Case Study in the Chemoja Watershed, Blue Nile Basin, Ethiopia. Addis Ababa University, Addis Ababa.

[9] Rahaman, S.A., Aruchamy, S., Jegankumar, R. and Ajeez, S.A. (2015) Estimation of Annual Average Soil Loss Based on RUSLE Model in Kallar Watershed, Bhavani Basin, Tamil Nadu, India. ISPRS Annals of the Photogrammetry, Remote Sensing and Spatial Information Sciences, II-2/W2, 207-214.

https://doi.org/10.5194/isprsannals-II-2-W2-207-2015

[10] Renard, K., Foster, G., Weesies, G., Mcool, D. and Yoder, D. (1995) The Revised Universal Soil Loss Equation. Department of Defense/Interagency Workshop on Technologies to Address Soil Erosion on Department of Defense Lands, San Antonio, TX.

[11] Angima, S., Stott, D., O’Neill, M., Ong, C. and Weesies, G., (2003) Soil Erosion Prediction Using RUSLE for Central Kenyan Highland Conditions. Agricultural, Ecosystems and Environment, 97, 295-308. https://doi.org/10.1016/S0167-8809(03)00011-2

[12] Yahya, F., Dalal Z. and Ibrahim F. (2013) Spatial Estimation of Soil Erosion Risk Using RUSLE Approach, RS, and GIS Techniques: A Case Study of Kufranja Catchment, Northern Jordan. Journal of Water Resource and Protection, 5, 1247-1261. https://doi.org/10.4236/jwarp.2013.512134

[13] Shi, Z., Cai, C., Ding, S., Wang, T. and Chow, T. (2003) Soil Conservation Planning at the Small Watershed Level Using RUSLE with GIS: A Case Study in the Three Gorge Area of China. Catena, 55, 33-48.

[14] Hudson \& Fall (2005) Soil Erosion Modelling Using the Revised Universal Soil Loss Equation (RUSLE) in Drainage Basin in Eastern Mexico. Environmental GIS: GRG $360 \mathrm{G}$.

[15] Fogleman, B.D. (2009) Eroison Modelling: Use of Multiple Return and Base Areas Susceptible to Erosion. MacRidge, Training Area, Fort Bragg, NC.

[16] International Livestock Research Institute (1998) GIS Services. http://192.156.137.110/gis/postdownload.asp?dfile=zipfiles/kenya/Kenya_climate_s urface.zip

[17] Hurni (1985) Soil Conservation Manual for Ethiopia. Ministry of Agriculture, Addis Ababa.

[18] (2016) Rainfall Data. Kenya Meteorological Department, Nairobi.

[19] Regional Centre for Mapping of Resources and Development (RCMRD), Nairobi, Kenya.

[20] Nelson, N. and Baldock, A. (2000) Soil Organic Matter. Handbook of Soil Science, Chapter 2, CRC Press, Boca Raton, B25-B84.

[21] United States Geological Survey (USGS)-USGS. Aster Digital Elevation Model (DEM) Resolution of 30 Metres Website. https://gdex.cr.usgs.gov/gdex/

[22] Moore, I.D. and Burch, G.J. (1986) Physical Basis of the Length Slope Factor in the Universal Soil Loss Equation. Soil Science Society of Agricultural Engineering, 50, 1294-1298. https://doi.org/10.2136/sssaj1986.03615995005000050042x

[23] Moore, I.D. and Burch, G.J. (1986) Modeling Erosion and Deposition. Topographic Effects. Transactions of American Society of Agriculture Engineering, 29, 1624-1630. https://doi.org/10.13031/2013.30363

[24] Admin (2015) Calculating Vegetation Indices from Landsat Image Using ArcGIS 10.1. School of the Environment University of Toronto. 
http://grindgis.com/blog/vegetation-indices-arcgis

[25] Durigon, V., Carvalho, D., Antunes, M., Almeid, W. and Oliveira, P. (2014) Predicting Soil Erosion Using RUSLE and NDVI Time Series from TM Landsat 5. Pesquisa Agropecuária Brasileira, 49, 215-224.

[26] Gizachew, A. (2015) A Geographical Information System-Based Soil Loss and Sediment Estimation in Zingin Watershed for Conservation Planning, Highlands of Ethiopia. International Journal of Science, Technology and Society, 3, 28-35.

[27] Mbugua, W. (2009) Using GIS Techniques to Determine RUSLE's R and LS Factors for Kapingazi River Catchment.

http://citeseerx.ist.psu.edu/viewdoc/download;jsessionid=06915738208472B183C24 $\underline{\text { BB177EE60ED?doi=10.1.1.603.9304\&rep=rep1\&type }=\text { pdf }}$

[28] Jankauskas, B., Jankauskiene, G. and Fullen, M. (2007) Relationship between Soil Organic Matter Content and Soil Erosion Severity in Albeluvisols of the Zemaiciai Uplands. Ekologija, 53, 21-28.

[29] Wischmeier, W. and Mannering, J. (1969) Relation of Soil Properties to Its Erodibility. Soil Science Society of America Proceedings, 33, 131-137. https://doi.org/10.2136/sssaj1969.03615995003300010035x

[30] Okoth, E.A. (2006) Characterization and Assessment of Erosion Susceptibility of the Soils of Mount Marsabit Ecosystem. University of Nairobi Thesis Abstract, Nairobi.

[31] Birham, A. (2016) Quantification of Soil Loss Using GIS and Remote Sensing in Northern Ethiopia. Esri Eastern Africa Education GIS Conference, Addis Ababa, 23-24 September 2016, 126-136.

[32] Nelly, S. (2013) Risk Assessment Analysis of Soil Erosion Using Geographic Information System. A Case Study of Taita Hills, Kenya. Department of Geospatial and Space Technology, University of Nairobi, Nairobi.

[33] Hurni, H. (1993) Land Degradation, Famine and Resource Scenarios in Ethiopia. In: Pimentel, D., Ed., World Soil Erosion and Conservation, Cambridge University Press, Cambridge, 27-62. https://doi.org/10.1017/CBO9780511735394.004

[34] Sombroek, W., Braun, H. and Pouw, B. (1980) Exploratory Soil Map and Agro-Climatic Zone Map of Kenya. Exploratory Soil Survey Report No. E1, Nairobi.

[35] Bonarius, H. (1975) Kenya Soil Survey, Preliminary Assessment of Irrigation Development in the Marsabit Area: Special Task Force, Minor Irrigation Development, Ministry of Agriculture, Republic of Kenya. Scanned from Original by ISRIC-World Soil Information, as ICSU, World Data Centre for Soil.

[36] Panagos, P., Borreli, P., Meusburger, K., Zanden, E., Poesen, J. and Alewell, C. (2015) Modelling the Effect of Support Practices (P-Factor) on the Reduction of Soil Erosion by Water at European Scale. Environmental Science and Policy, 51, 23-34. https://doi.org/10.1016/j.envsci.2015.03.012 


\section{Appendices}

\section{Appendix I. Kenya Ecological Zones}

Kenya is divided into five altitude zones and seven moisture availability zones. The annual rainfall divided by potential evaporation gives moisture availability. The altitude zones are sea level to $200 \mathrm{~m}, 200-1500 \mathrm{~m}, 1500-2500 \mathrm{~m}, 2500$ $3000 \mathrm{~m}$ and $>3000 \mathrm{~m}$. The moisture availability zones include very arid (zone VII), arid (Zone VI), semi-arid (zone V), semi-humid to semi-arid (zone IV), semi-humid (zone III), sub-humid (zone II) and humid (zone I). Areas designated as I, II and III with a moisture index greater than $50 \%$ have a high potential for cropping (Sombroek, et al., 1982). The high agricultural potential areas are located above $1200 \mathrm{~m}$ altitude with a mean annual temperature of below $18^{\circ} \mathrm{C}$ while $90 \%$ of the semi-arid and arid zones lie below $1200 \mathrm{~m}$ a.s.l with a mean annual temperature ranging from $22^{\circ} \mathrm{C}$ to $40^{\circ} \mathrm{C}$.

Table A1. Kenya's ecological zones.

\begin{tabular}{ccccc}
\hline ZONE & CLASSIFICATION & MOISTURE\% & ANNUAL RAINFALL & \% OF KENYA'S AREA \\
\hline $1 \mathrm{~V}$ & Semi-humid to semi-arid & $40-50$ & $600-1100$ & 5 \\
$\mathrm{~V}$ & Semi-arid & $25-50$ & $450-900$ & 22 \\
$\mathrm{VII}$ & Very arid & $<15$ & $150-350$ & 46 \\
\hline
\end{tabular}

${ }^{1}$ Kenya's four out of seven ecological zones whose moisture index falls below $50 \% .{ }^{2}$ Target research area falls under semi humid to semi-arid. Source: Sombroek, et al., (1982).

\section{Appendix II. Soil Erodibility Factor Maps}

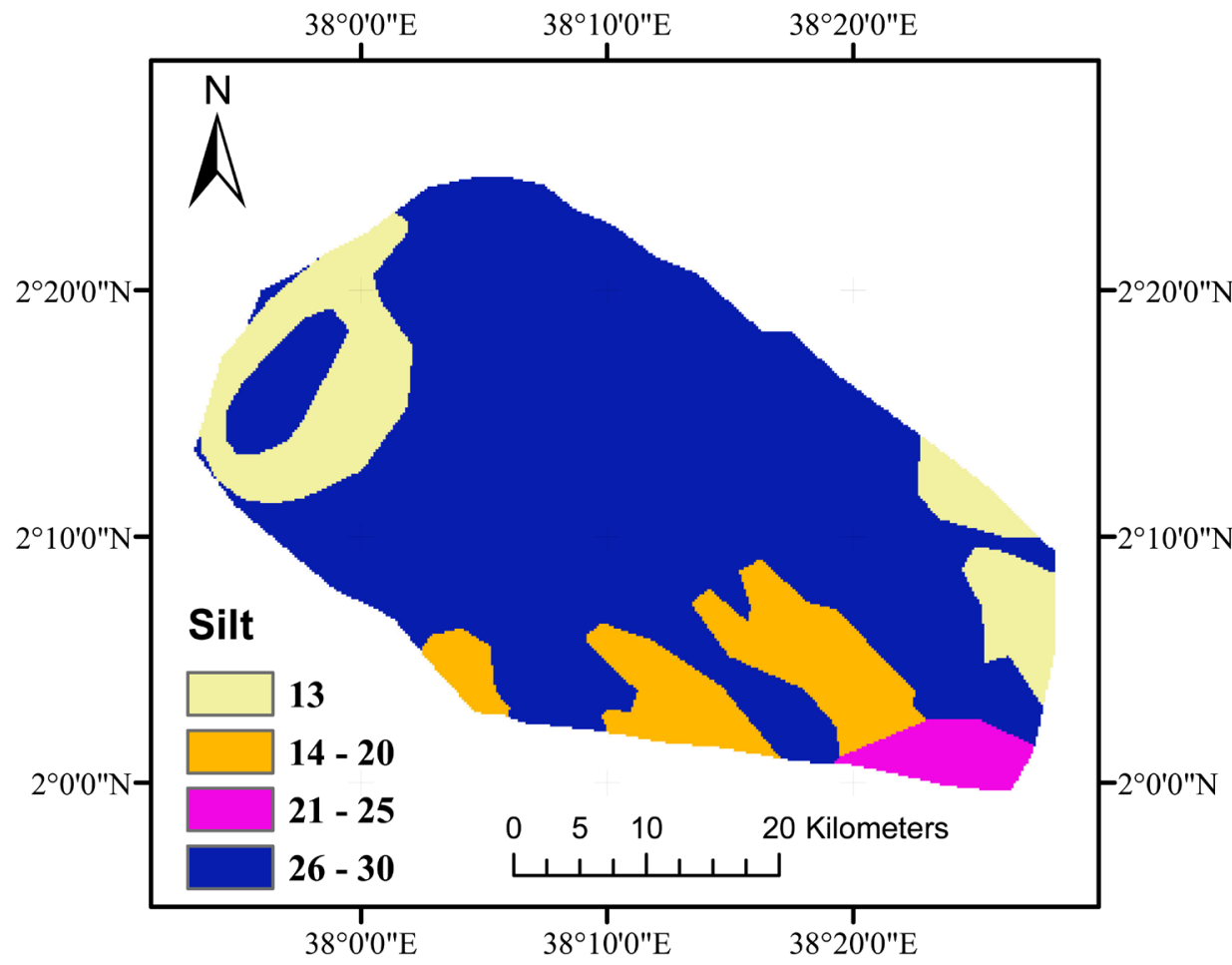

Figure A1. Percentage silt map. 


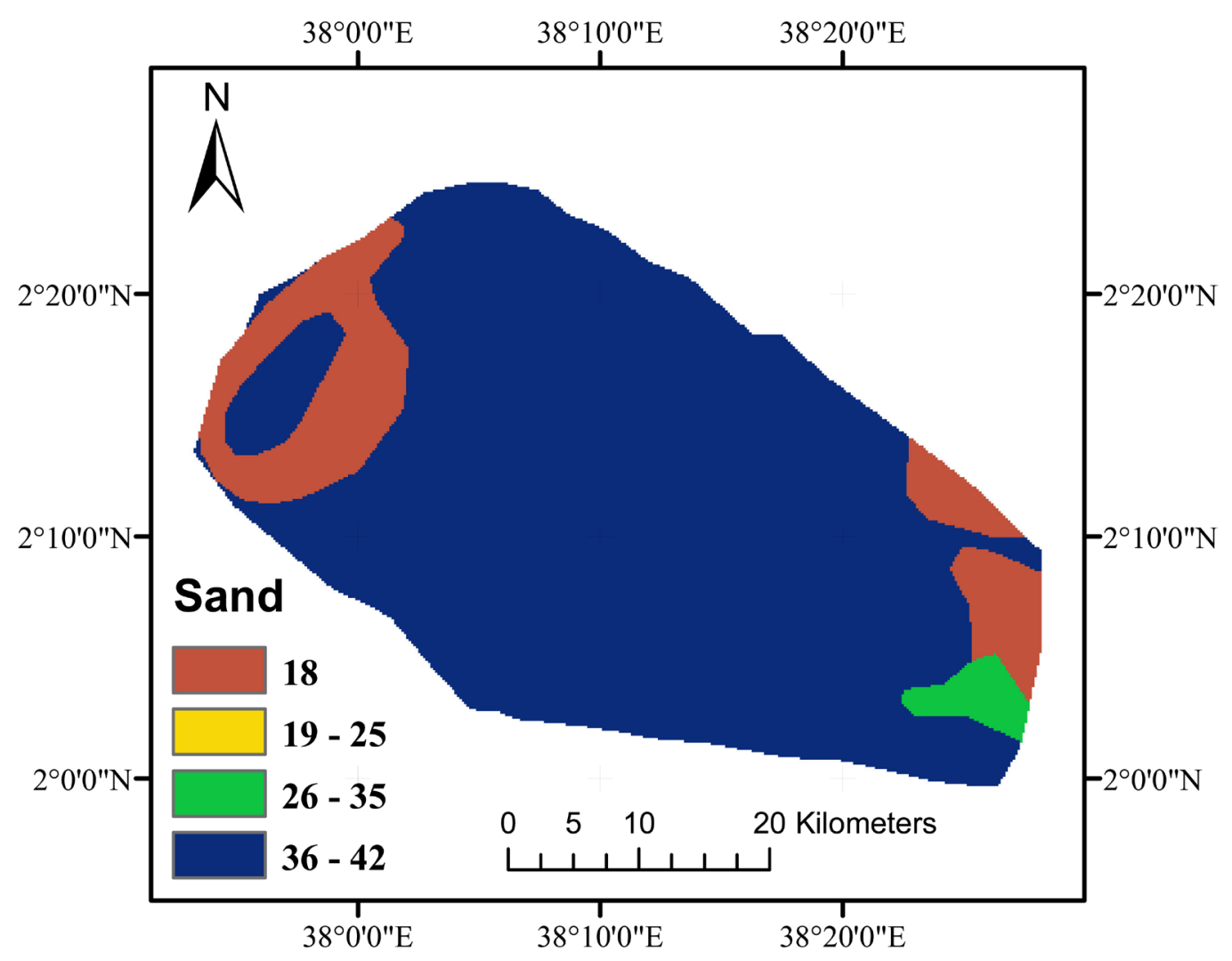

Figure A2. Percentage sand map.

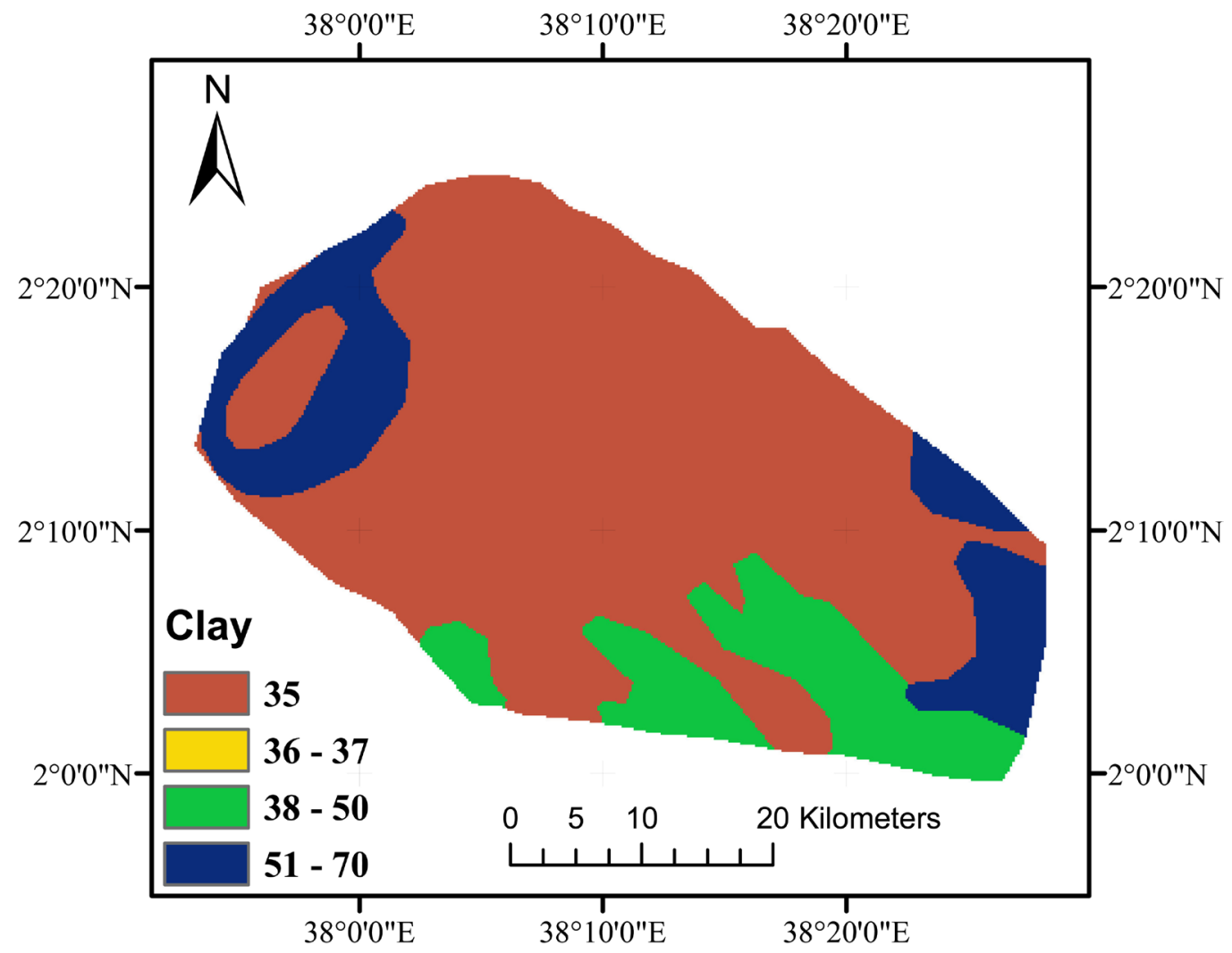

Figure A3. Percentage clay map. 


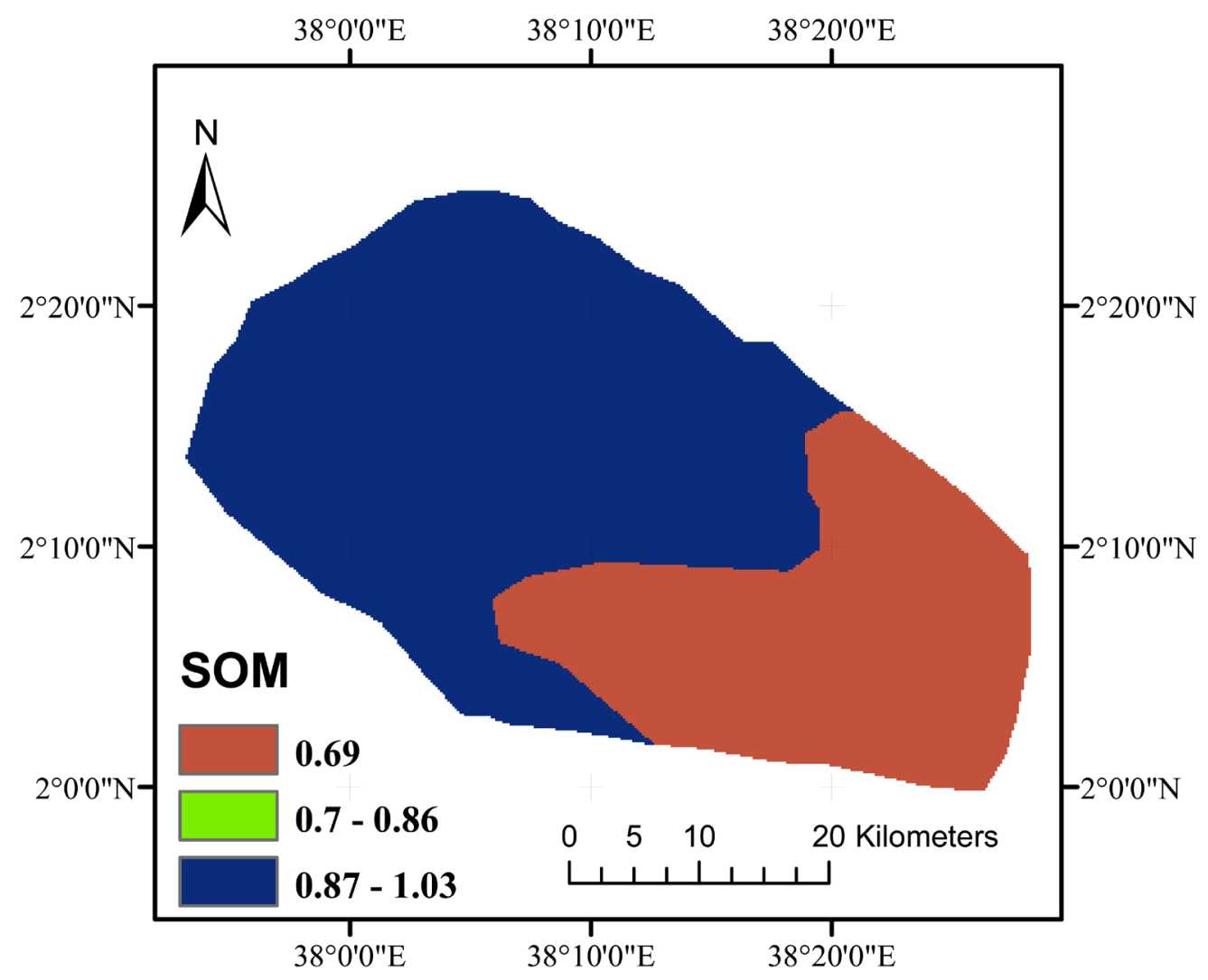

Figure A4. Soil organic matter (SOM) map.

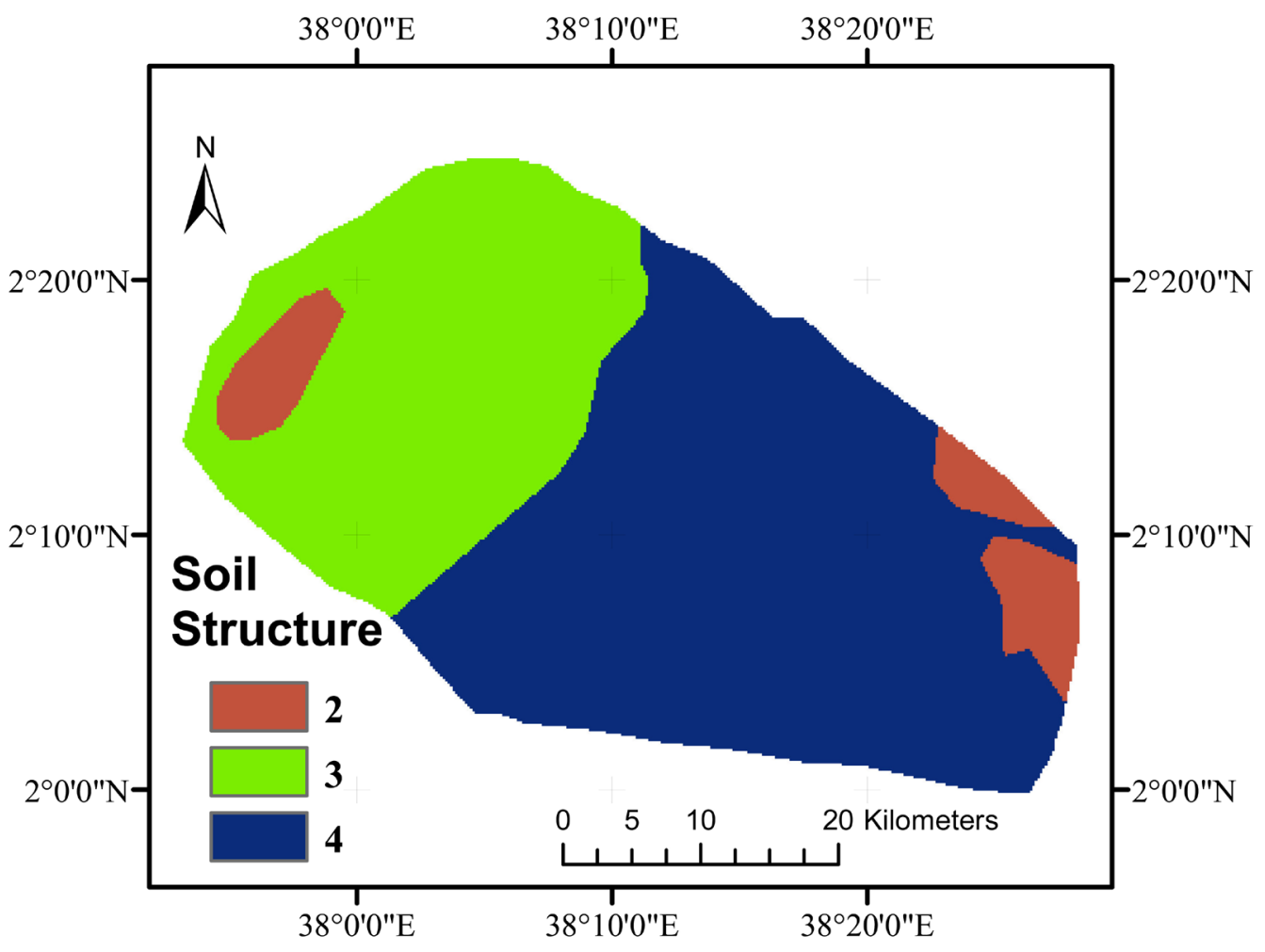

Figure A5. Soil structure code map. 


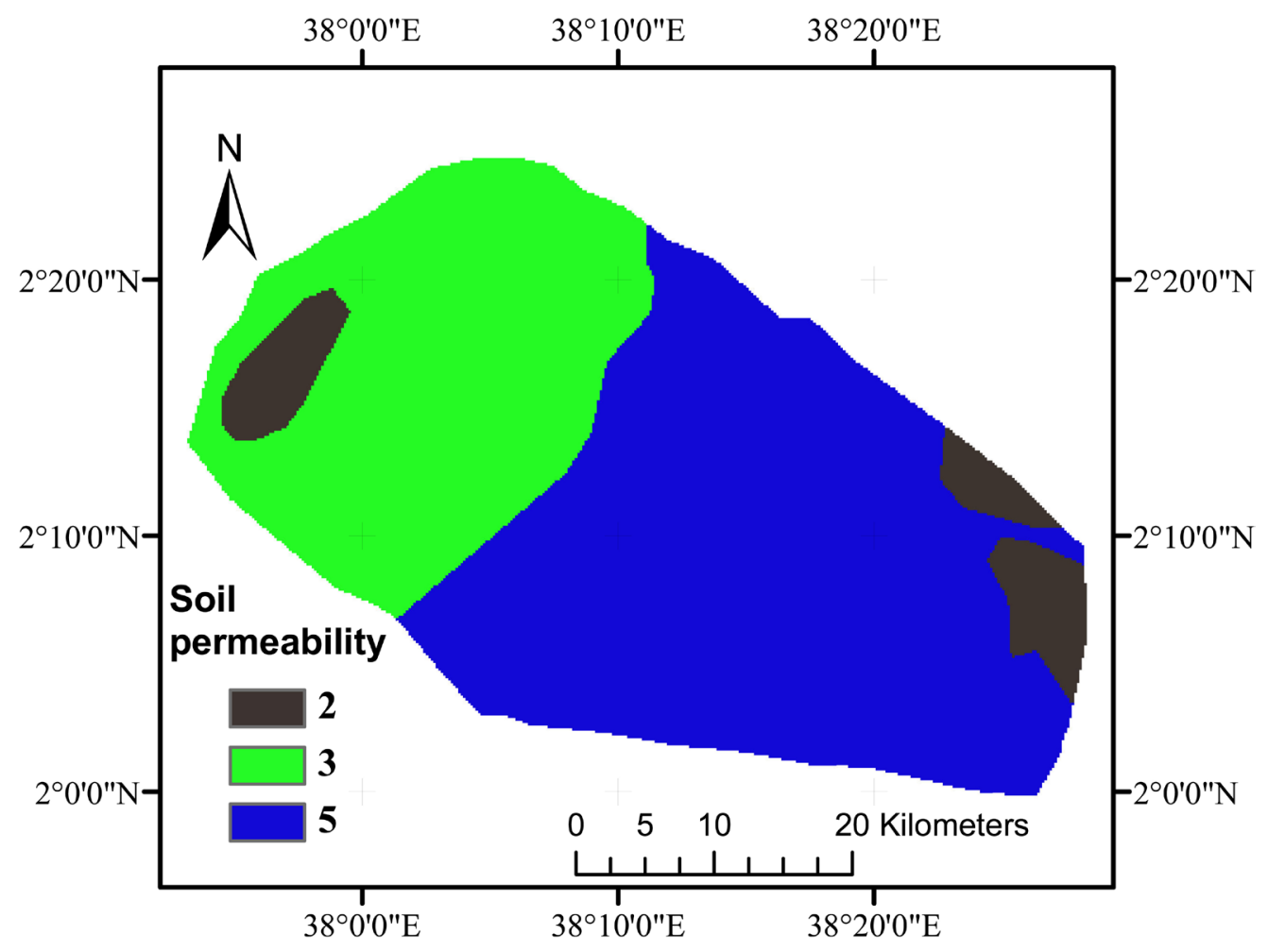

Figure A6. Soil permeability code map.

Appendix III. LS Factor Parameters Maps

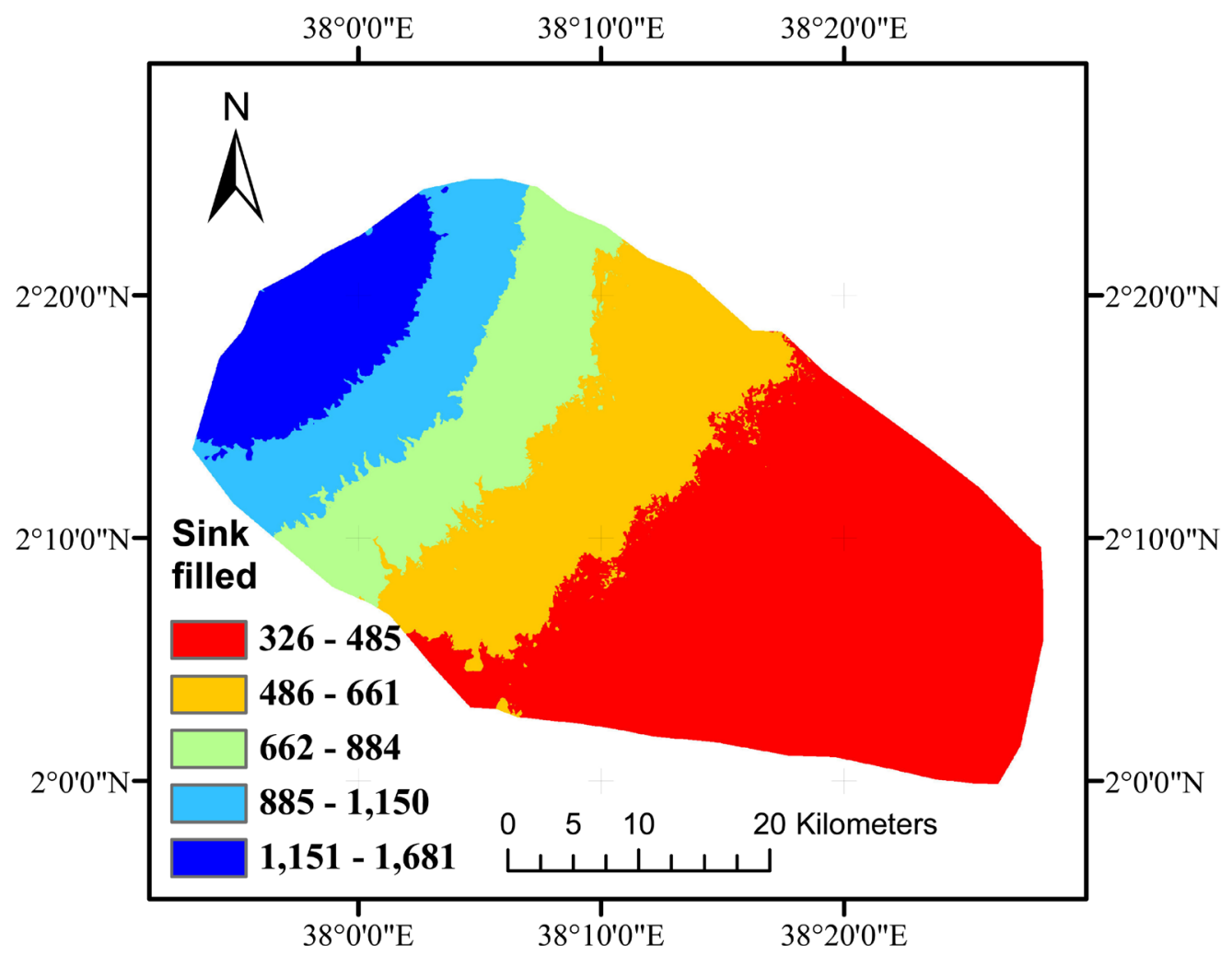

Figure A7. Sink filled map. 


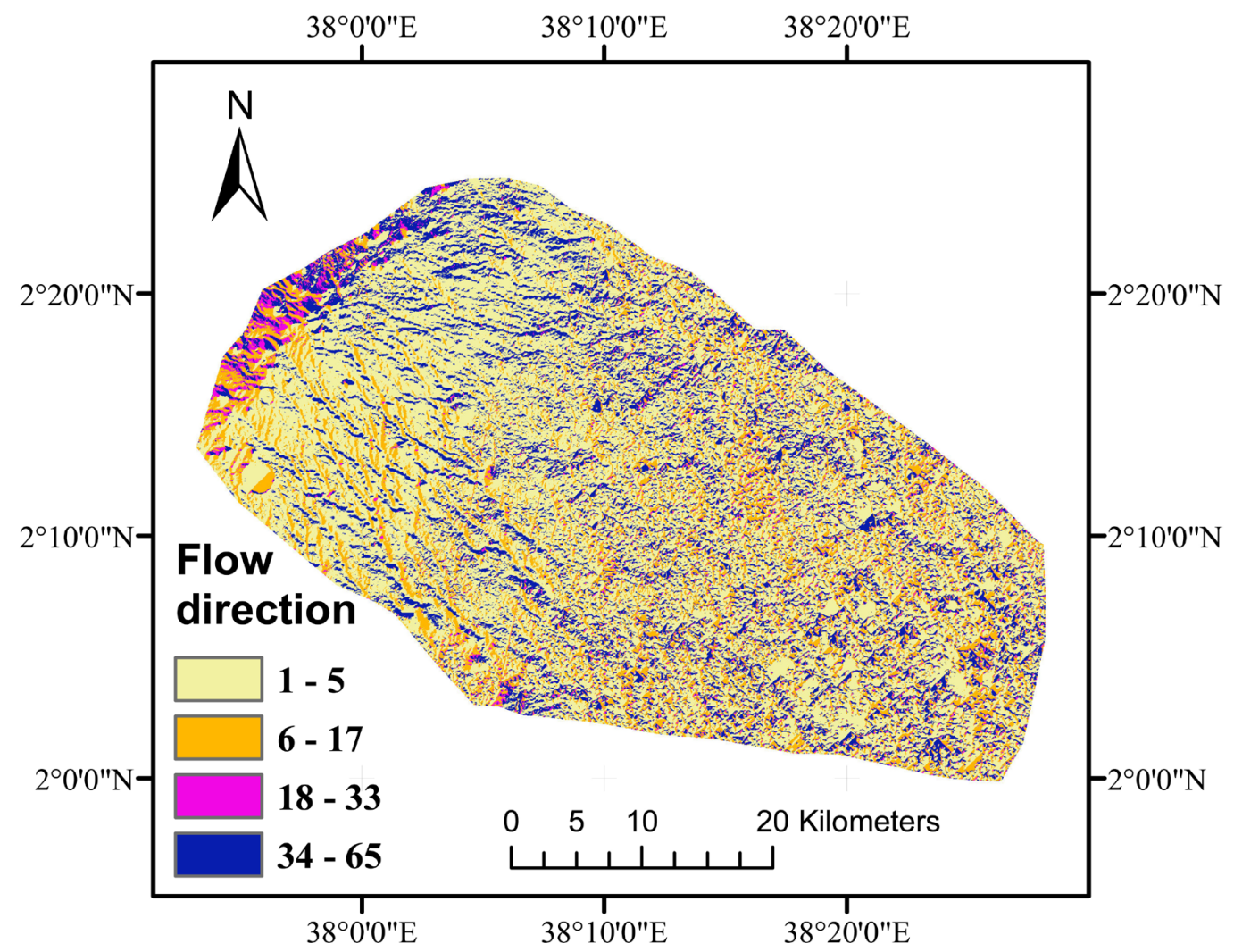

Figure A8. Flow direction map.

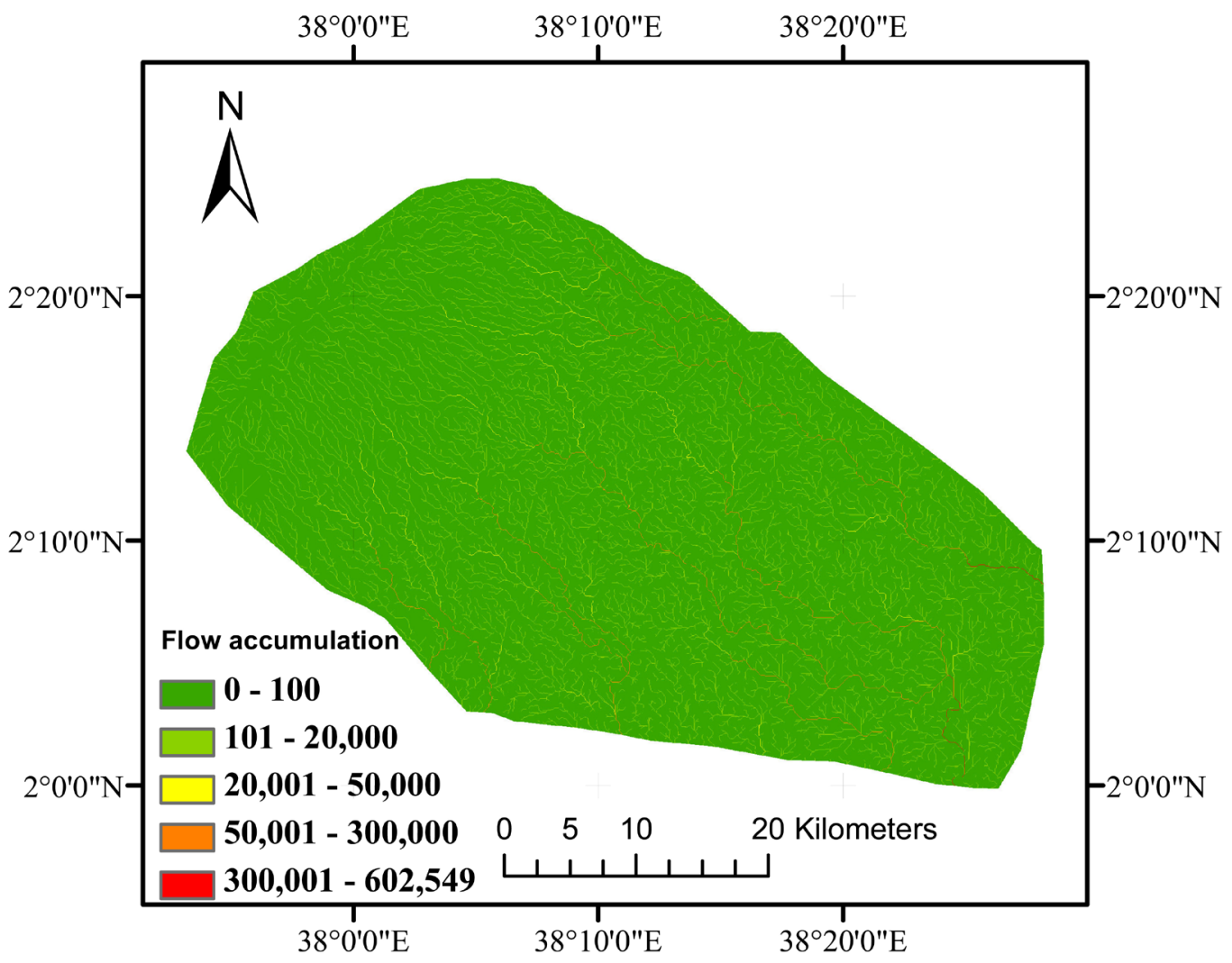

Figure A9. Flow accumulation map. 


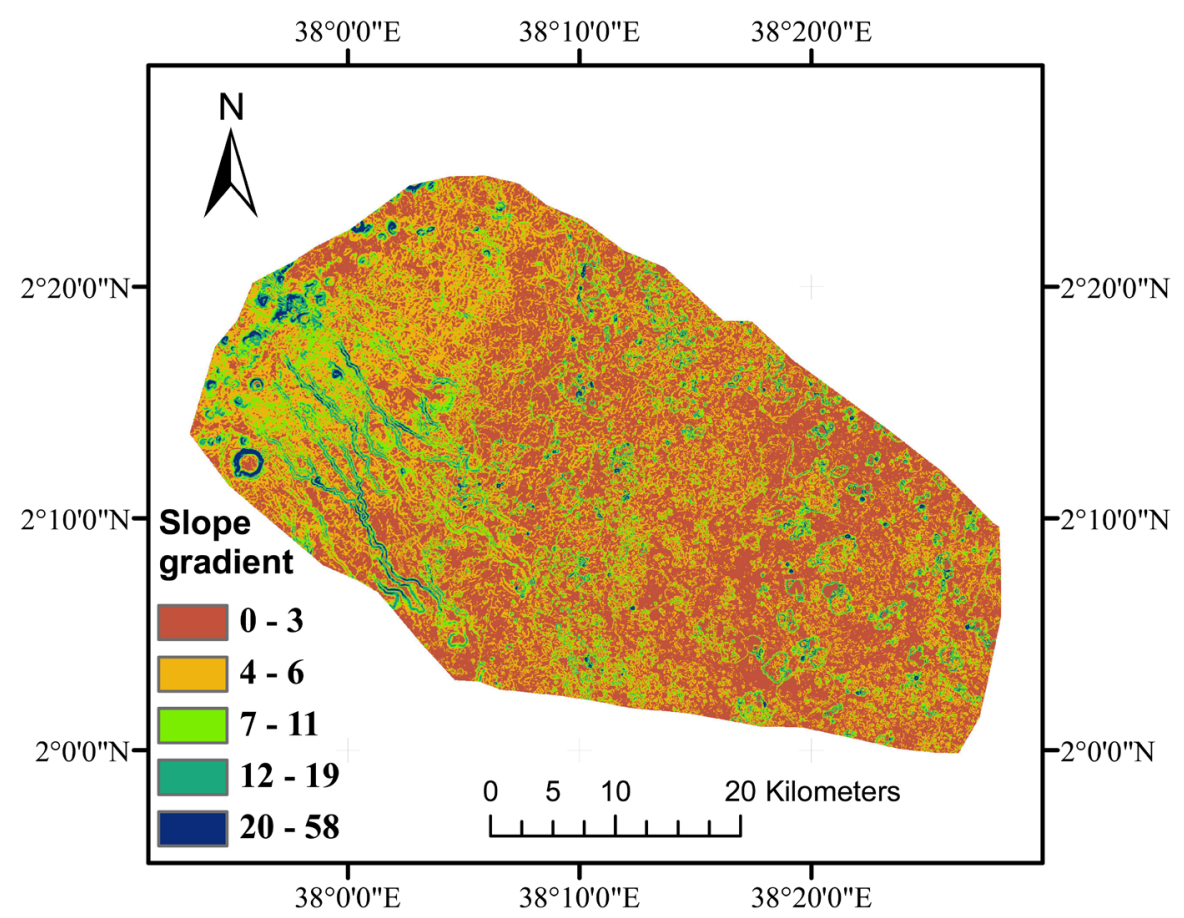

Figure A10. Slope gradient map.

\section{Appendix IV. C Factor Parameters Maps}

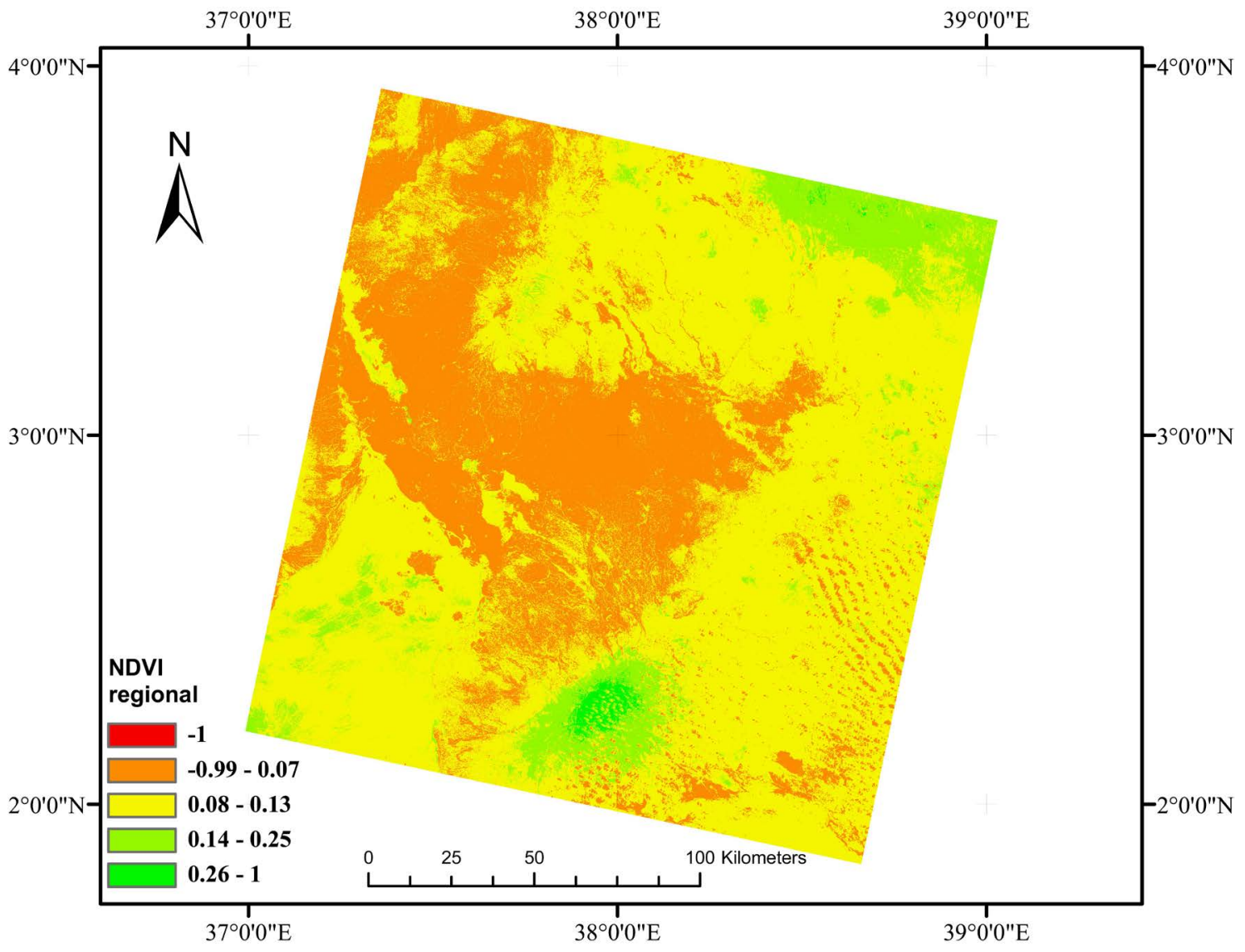

Figure A11. Regional NDVI. 


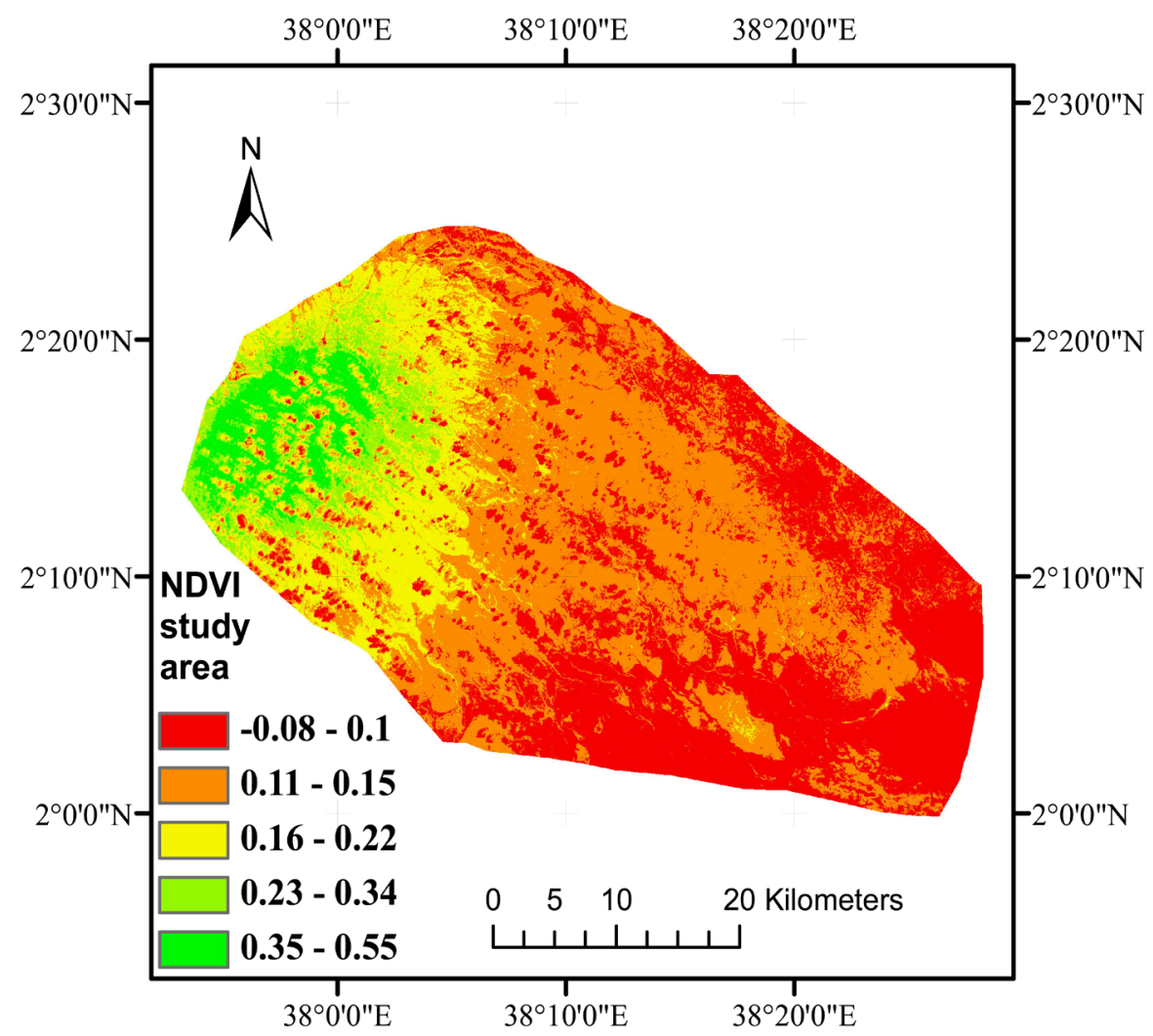

Figure A12. Study area NDVI.

Appendix V. P-Factor Maps

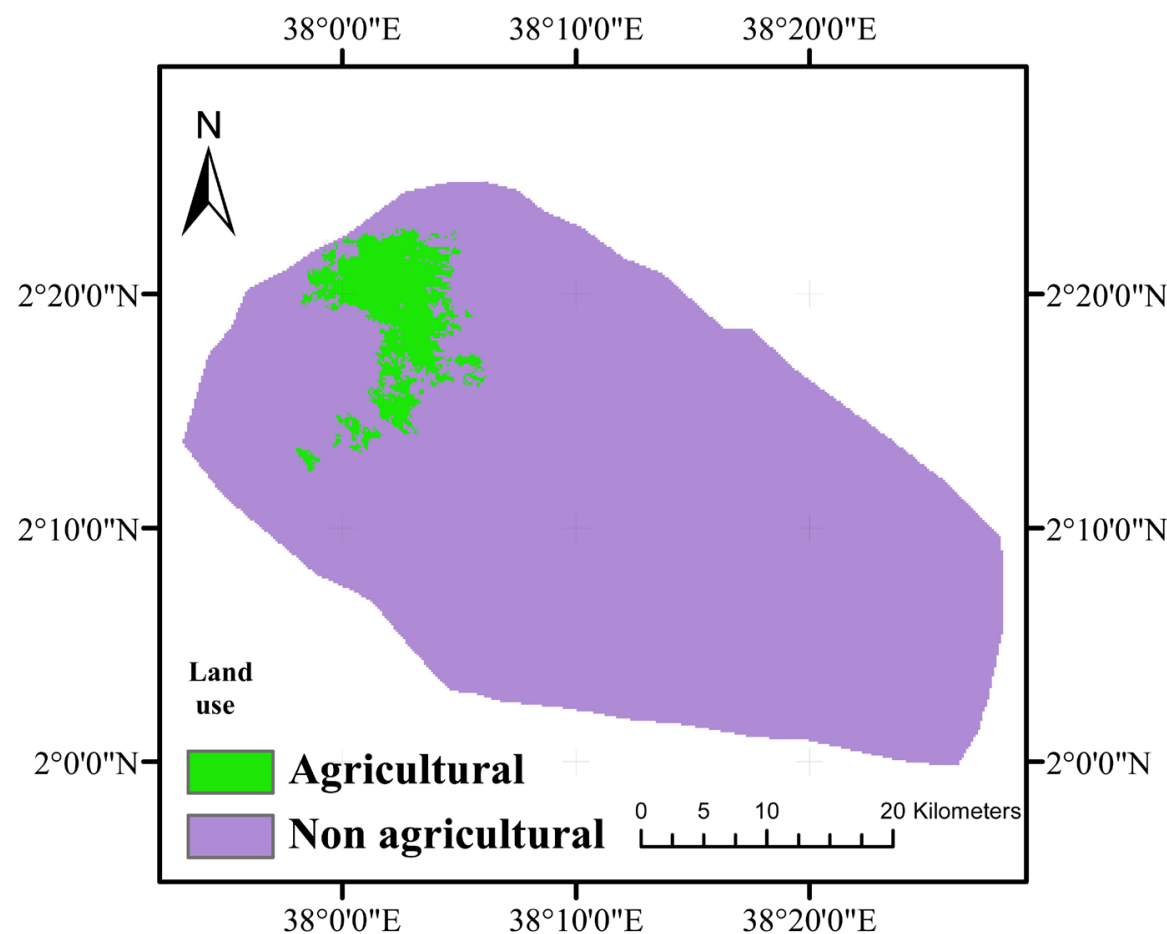

Figure A13. Land use map showing agricultural and non-agricultural areas of the study area. 


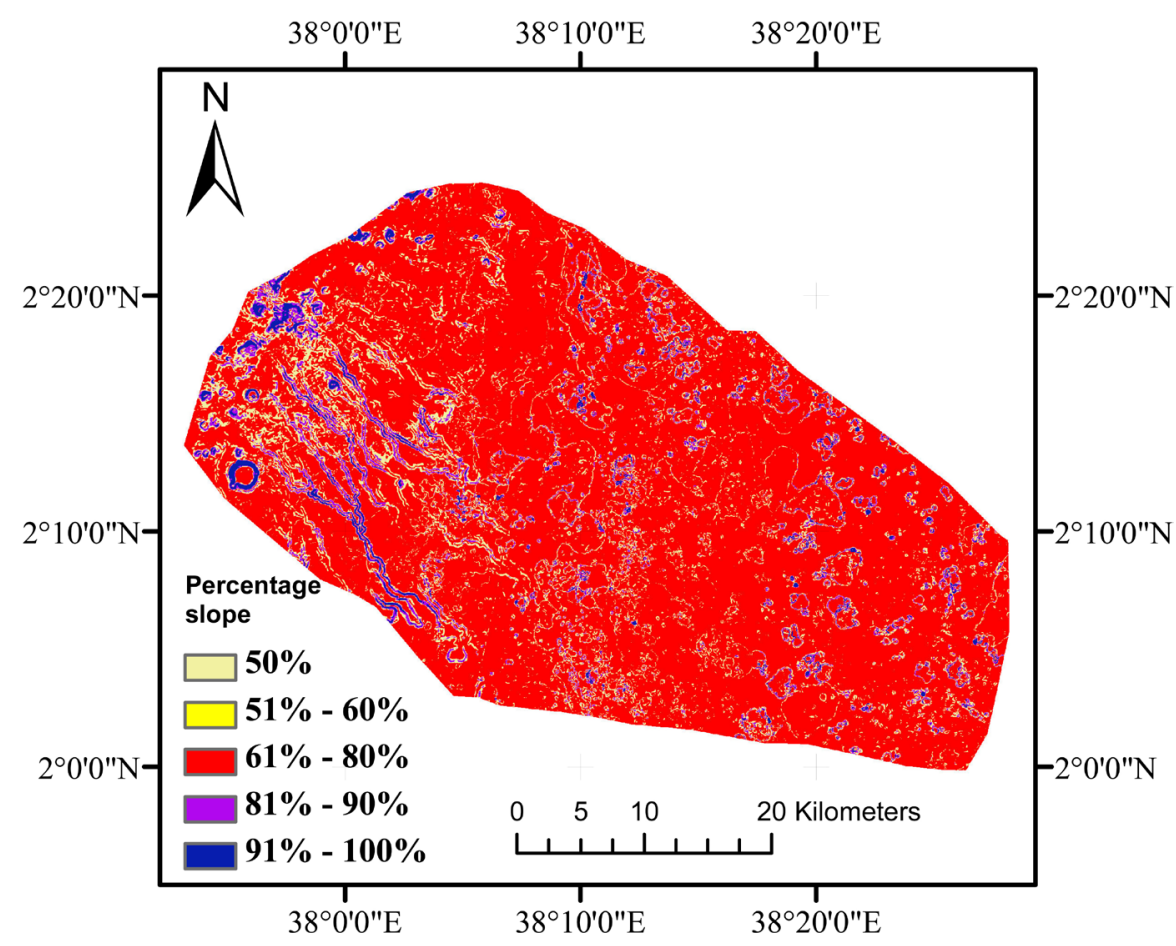

Figure A14. Reclassified slope map of the study area.

\section{Appendix VI}

Table A2. The major soil properties of the study area.

\begin{tabular}{cccccccc}
\hline Value & FAO soil units & CEC & Texture & $\begin{array}{c}\text { Structure } \\
(\mathrm{ST})\end{array}$ & $\begin{array}{c}\text { Permeability } \\
(\text { Perm })\end{array}$ & $\begin{array}{c}\text { ST } \\
\text { code }\end{array}$ & $\begin{array}{c}\text { Perm } \\
\text { code }\end{array}$ \\
\hline 1 & Lithosols & 4 & Loamy & Blocky & Moderate & 3 & 3 \\
2 & Chromic Cambisols & 4 & Loamy & Aggregate & High & 2 & 2 \\
3 & Pellic Vertisols & 4 & Clayey & Massive & Low & 4 & 5 \\
4 & Eutric Nitosols & 3 & Clay & Blocky & Moderate & 3 & 3 \\
5 & Mollic Andosols & 4 & Very clayey & Aggregated & High & 2 & 2 \\
6 & Calcic Xerosols/Yamosols & 3 & Clayey & Massive & Low & 4 & 5 \\
7 & Calcic Xerosols/Yamosols & 3 & clayey & Massive & Low & 4 & 5 \\
8 & Calcaric Fluvisols & 7 & Very clayey & Massive & Low & 4 & 5 \\
9 & Luvo-Orthic Solonetz & 4 & Clayey & Massive & Low & 4 & 5 \\
\hline
\end{tabular}

